\title{
Materiam superabat opus: Cervantes, cautivo lector de Rufo (al trasluz de la modalidad épico-novelesca en La Austriada y los Apotegmas)
}

\author{
FRANCISCO J. ESCOBAR \\ Universidad de Sevilla
}

Título: Materiam superabat opus: Cervantes, cautivo lector de Rufo (al trasluz de la modalidad épico-novelesca en La Austríada y los Apotegmas).

Resumen: El presente estudio arroja luz sobre el método épico-novelesco empleado por Miguel de Cervantes en su conocida historia del cautivo. Para ello, el autor del Quijote fue un atento lector de Juan Rufo, quien, entre la realidad histórica y la ficcionalización, cultivó tanto el canon épico como la tradición paremiológica, según queda de manifiesto en La Austríada y Apotegmas. Sin embargo, Cervantes supo encontrar, además, sus propias señas de identidad narrativas con el objeto de "mostrar con propiedad un desatino", entre otras estrategias humanísticas, gracias a su profundo conocimiento y asimilación de los modelos de la tradición clásica.
Title: Materiam superabat opus: Cervantes, captive reader of Rufo (by the light of the epicfictional modality in La Austríada and the Apotegmas).

Abstract: The present study sheds light on the epic-fictional method used by Miguel de Cervantes in his well-known story of the captive. For this, the author of the Quijote was an attentive reader of Juan Rufo, who, between historical reality and fictionalization, cultivated both the epic canon and the paremiological tradition, as is evident in La Austríada y Apotegmas. However, Cervantes was able to find, in addition, his own signs of narrative identity in order to "mostrar con propiedad un desatino", among other humanistic strategies, thanks to his deep knowledge and assimilation of the models of the classical tradition.

Key words: Miguel de Cervantes, Juan Rufo, Quijote, historia del cautivo, La Austríada, Apotegmas.

Date of Receipt: 30/9/2018.

Fecha de recepción: 30/9/2018.

Date of Approval: 9/10/2018.

Fecha de aceptación: 9/10/2018. 
De Juan Gutiérrez Rufo el claro nombre quiero que viva en la inmortal memoria, y que al sabio y al simple admire, asombre la heroica que compuso ilustre historia.

Dele el sagrado Betis el renombre que su estilo merece; denle gloria los que pueden y saben; dele el cielo igual la fama a su encumbrado vuelo.

Cervantes, La Galatea, VI, 473-480.

\section{Cervantes cautivo lector de Rufo: Cuestiones preliminares}

Entre los caminos de experimentación estética trazados por los escritores áureos a partir de la década de los ochenta del siglo XVI, se alza, en un lugar preeminente, el maridaje conceptual de realidad y ficción con el objeto, en términos cervantinos, de "mostrar con propiedad un desatino" Un excelente ejemplo de dicho proceder metodológico se encuentra, no obstante, en la lectura que Miguel de Cervantes hizo de Juan Gutiérrez Rufo (o Juan Rufo), autor, como se sabe, de La Austríada (Madrid, en casa de la viuda de Alonso Gómez, 1584), con reediciones en Toledo, Juan Rodríguez, 1585, así como Alcalá de Henares, Juan Gracián, 1586, además de sus conocidos Apotegmas (Toledo, Pedro Rodríguez, 1596)². En esta última obra, en concreto en el Apot. 662, "Materiam superabat opus", al hilo de un sutil guiño a Ovidio, Met., II, 5, pone de relieve ya cómo la formalización, el modo narrativo y la factura estética sustentada

1 En concreto: "Yo he abierto en mis Novelas un camino, / por do la lengua castellana puede / mostrar con propiedad un desatino" (Viaje del Parnaso, IV, 25-27); véase: Miguel de Cervantes, "Viaje del Parnaso" y poesías sueltas, ed. José Montero Reguera y Fernando Romo Feito, col. Macarena Cuiñas Gómez, Madrid, Real Academia Española, 2016, p. 61.

2 Citaré los textos de Juan Rufo por las siguientes ediciones: Las seiscientas apotegmas y otras obras en verso, ed. Alberto Blecua, Madrid, Espasa-Calpe, 1972 (reed.: Sevilla, Fundación José Manuel Lara, 2006); y La Austríada, ed. Ester Cicchetti, Como Pavia, Ibis, 2011. Sobre la vida y producción estética de Rufo, como visión de conjunto: Rafael Ramírez de Arellano, Juan Rufo, Jurado de Córdoba: estudio biográfico y crítico, Valladolid, Editorial Maxtor Librería, 2002. 
sobre la ficcionalización resultaban superiores a la materia o el contenido, habitualmente inspirados en la realidad, de los que se nutría la obra ${ }^{3}$.

Por ello no es de extrańar, a efectos de poética narrativa, que en Apot. 554 Rufo desvele su concepto de "Novela que, pareciendo gran mentira, fuese verdad o tuviese apariencia dello" . De hecho, un cautivo y cautivado lector como Cervantes supo estar atento a estas nociones literarias en su deseo de encontrar, como sucedería con el tiempo, un método, mesa de trucos o tropelía que le permitiese "mostrar con propiedad un desatino". Es más, en La Austríada, obra en cuyos preliminares el escritor alcalaíno colaboró (véase infra), Rufo vuelve sobre dicho interés al trasluz de la dualidad historia verdadera - historia fingida o ficta, según se refleja en el prólogo, fechado en Madrid el 20 de marzo de 1582 (“[...] para que siempre biva en la [memoria] de los hombres la verdadera historia que en verso escriví”) $)^{5}$. Lo hace el Jurado de Córdoba, no obstante, más allá de meras orientaciones como accessus ad auctorem a los lectores, entre los que se encontraba, y de los primeros bien avisados, Cervantes, sobre las cualidades del discurso intersubjetivo y la ejemplaridad, e incluso del ritual épico con puntos de encuentro respecto a otros distinguidos autores como Barahona de Soto o Balbuena ${ }^{6}$; o lo que viene a ser lo mismo, en las lábiles fronteras entre la veracidad, el verismo y la verosimilitud, incluyendo el "espacioso campo" tan habitual en el usus scribendi del autor alcalaíno, desde $L a$ Galatea 7 y el conocido precepto de la poética horaciana de de-

3 Juan Rufo, op. cit., pp. 229-230.

4 Juan Rufo, op. cit., p. 194.

5 Juan Rufo, op. cit., p. 891. Con otros apuntes complementarios a nivel conceptual tales como "su Alteza me mandó ocupar en escrivir su vida, que, con ser breve, dio larga materia en que bolassen muchas plumas mejores que la mía [...].”; y “[...] a cuya instancia determiné sacar a luz esta primera parte de mi escriptura [...]." (Ibidem).

6 Vid. Raúl Díaz Rosales, "La apertura épica. El 'ritual introductorio' en Rufo, Barahona de Soto y Balbuena”, en Congreso Internacional Andalucía Barroca: Actas. Iglesia de San Juan de Dios de Antequera, 17-21 de septiembre de 2007, coord. Alfredo J. Morales, Sevilla, Junta de Andalucía, Consejería de Cultura, 2009, vol. 3, pp. 275-280.

7 Para otros pormenores sobre esta imagen puede leerse: Miguel de Cervantes, $L a G a$ latea, ed. Juan Montero, en colaboración con Francisco J. Escobar y Flavia Gherardi, Madrid - Barcelona, Real Academia Española - Galaxia Gutenberg - Círculo de Lectores, 2014, pp. 14-15 y 611; en cuanto al elogio de Rufo y La Austríada ("la heroica que compuso ilustre historia.") por Cervantes en el Canto de Caliope, véase la p. 380. 
jar pasar diez años de cara a la divulgación de una obra, con resonancias tanto en el prólogo del Quijote de 1605 como en El coloquio de los perros:

En cuanto al hecho de la verdad de las cosas que trato, forçosamente havrá diferentes opiniones, como las hay en todos los casos de que muchos deponen. Lo que yo pude hazer fue en las evidencias estar a lo cierto, y en las dudas atenerme a lo verisímil, porque si esta no fuera mi intención, más espacioso campo hallara para escrivir, y más oportunidad para explicarme en otros sujetos de invención que en el de historia, y tan moderna. De dos cosas no se me podrá hazer cargo: la una, de que no tomé el consejo de Horacio, pues gasté diez ańos de perpetuo estudio en componer y limar este tratado; y la otra, de que antes de sacalle en público no consulté gravíssimos tribunales, por cuyo aplauso y autoridad fui no solo cohortado, pero casi compelido a manifestarlo, como constará por lo precedente ${ }^{8}$.

Pues bien, en dicho preliminar, la "verdad de las cosas", vinculada por parte de Rufo al precepto de atenerse "a lo verisímil", no deja de recordar la "verdad del caso", tan presente en el concepto novelístico de Cervantes, que ejemplificaré, en las páginas que siguen, en la historia del cautivo (Quijote I, 39-41) 9 y su "verdad del caso" ${ }^{10}$ como conformación de una

8 Juan Rufo, op. cit., p. 892. En consonancia además con otras aclaraciones ańadidas por parte de Rufo en este preliminar dedicado "Al lector": "[...] y aunque pudiera excusarme con dezir que esta obra es una curiosidad escripta en verso, y que no está obligada a ser historia general [...]."; y "Los defetos que fueren enmendables me hallarán oyéndolos detrás de la tabla con el pincel en la mano, obediente a cualquiera que alegare verdad, por rústico que sea." (ibid.).

9 Para ello citaré en lo sucesivo por la siguiente edición: Miguel de Cervantes, Don Quijote de la Mancha. Ed. Instituto Cervantes 1605-2005, dir. Francisco Rico, Barcelona, Centro para la Edición de los Clásicos Españoles - Galaxia Gutenberg Círculo de Lectores, 2004, 2 vols., con reimp. de 2012, pp. 493-540.

10 En cuanto a la "verdad del caso" en la historia del cautivo: Alicia Parodi, "El episodio del cautivo, poética del Quijote: verosímiles transgredidos y diálogo para la construcción de una alegoría”, en Actas del II Coloquio Internacional de la Asociación de Cervantistas, Barcelona, Anthropos, 1990, pp. 433-442; y Michael McGaha, "Hacia una verdadera historia del cautivo Miguel de Cervantes", Revista canadiense de estudios hispánicos, 20.3 (1996), pp. 540-546. Para otros detalles entre la historia verdadera y la novela histórica: Emilio González López, "Cervantes, maestro de la novela histórica contemporánea: la historia del cautivo", en Homenaje a Casalduero: 
renovada e híbrida modalidad genérica ${ }^{11}$; así, por ejemplo, como se recordará de entrada, cuando el renegado cervantino hace de avezado intérprete entre el capitán cautivo y Zoraida ${ }^{12}$, con cartas de amor de por medio ${ }^{13}$. De hecho, el renegado relata la "verdad" de un caso sobre unos caballeros cristianos desde su experiencia del cautiverio y la libertad como el bien más preciado ${ }^{14}$, en tanto que el cura, por su parte, viene a manifestar que

crítica y poesía, coord. Gonzalo Sobejano y Rizel Pincus Sigele, Madrid, Gredos, 1972, pp. 179-187.

11 Para esta híbrida naturaleza genérica con puntos de encuentro además respecto a la tradición épica de frontera, véase Stanislav Zimic, "Un sueño romántico de Cervantes: «El cuento del cautivo» (Don Quijote, I, caps. 37-42)”, Angélica. Revista de literatura, 6 (1994), pp. 37-66; Alberto Montaner Frutos, "La "derrota compuesta» del cautivo. (Quijote, I, XLI)", Anales cervantinos, 37 (2005), pp. 45-106; id., "La historia del capitán cautivo y la tradición épica de frontera", Letras. Revista de la Facultad de Filosofía y Letras de la Pontificia Universidad Católica Argentina Santa María de los Buenos Aires, 52-53 (2005-2006), pp. 73-115; así como Ernesto Lucero Sánchez, "«La historia del capitán cautivo» en el proceso de gestación de un nuevo género literario", en Cervantes y su tiempo, coord. Desirée Pérez Fernández, Juan Matas Caballero y José M. ${ }^{a}$ Balcells, León, Secretariado de Publicaciones y Medios Audiovisuales de la Universidad, 2008, vol. 1, pp. 85-96.

12 En lo que atañe a la caracterización de Zoraida como personaje cervantino: Marina S. Brownlee, «Zoraida’s White Hand and Cervantes' Rewriting of History», Bulletin of Hispanic Studies, 82.5 (2005), pp. 569-587, con un estado de la cuestión.

13 Cf.: "[...] Y, así, nos rogó que si era verdad lo que sospechaba, que nos fiásemos dél [del renegado] y se lo dijésemos, que él aventuraría su vida por nuestra libertad."; y "Con tantas lágrimas y con muestras de tanto arrepentimiento dijo esto el renegado, que todos de un mesmo parecer consentimos y venimos a declararle la verdad del caso, y, así, le dimos cuenta de todo, sin encubrirle nada" ( Miguel de Cervantes, op. cit., p. 512).

14 Cf.: "[...] porque el gozo de la libertad alcanzada y el temor de no volver a perderla les borraba de la memoria todas las obligaciones del mundo. Y en confirmación de la verdad que nos decía nos contó brevemente un caso que casi en aquella mesma sazón había acaecido a unos caballeros cristianos, el más estraño que jamás sucedió en aquellas partes, donde a cada paso suceden cosas de grande espanto y de admiración." (Miguel de Cervantes, op. cit., p. 515); "En todos nuestros discursos dimos muy lejos de la verdad del caso, y así, todo nuestro entretenimiento desde allí adelante era mirar [...]; pero bien se pasaron quince días en que no la vimos, [a Zoraida] ni la mano tampoco, ni otra señal alguna." (Cervantes, op. cit., p. 509); y “-Gualá, cristiano, [se dirige Agi Morato al cautivo] que debe de ser muy hermosa si se parece a mi hija, que es la más hermosa de todo este reino. Si no, mírala bien y verás como te digo verdad." (Miguel de Cervantes, op. cit., p. 522). Véanse al respecto: M. a Antonia Garcés Arellano, “"Se- 
el capitán le "contó un caso que a su padre con sus hermanos le había sucedido, que, a no contármelo un hombre tan verdadero como él, lo tuviera por conseja de aquellas que las viejas cuentan el invierno al fuego. Porque me dijo que su padre había dividido su hacienda entre tres hijos que tenía, y les había dado ciertos consejos mejores que los de Catón"15.

Por lo demás, Cervantes venía preparando con anterioridad esta "verdad del caso" en lo que a la linealidad narrativa del Quijote se refiere, dado que a esta historia le había precedido el discurso de las armas y las letras del ingenioso caballero andante (I, 37-38), con cala y cata en la figura del soldado letrado, la "preeminencia de las armas contra las letras", el pensamiento de que con las armas "se despejan los mares de cosarios", el "embestirse dos galeras por las proas en mitad del mar espacioso", la alusión a los "endemoniados instrumentos de la artillería" o el "ejercicio de caballero andante"... ${ }^{16}$. Asimismo, no había faltado tampoco una imitación apuleyana previa a propósito de los cueros de vino $(\mathrm{I}, 35)^{17}$, o lo que es lo mismo, otro camino de exploración narrativa por parte de Cervantes, como iremos comprobando a propósito de El asno de oro ${ }^{18}$. En cualquier caso, tras estos apuntes preparatorios, acabará relatándose la "verdad del caso" en el que "don Fernando rogó al cautivo les contase el discurso de su vida"19, o sea, un "cuento" entre la verdad y la opinión, bien colectiva y/o individual, en la historia del cau-

ñor de nuestra libertad»: cuerpos y fronteras en «La historia del cautivo» (Don Quijote I, 37-41)", en Cervantes y el "Quijote»: Actas del coloquio internacional, Oviedo 27-30 de octubre de 2004 organizado por la Cátedra Emilio Alarcos, coord. Emilio Martínez Mata, Madrid, Arco/Libros, 2007, pp. 161-172; Paul Michael Johnson, "A Soldier's Shame: The Specter of Captivity in "La historia del cautivo", Cervantes. Bulletin of the Cervantes Society of America, 31.2 (2011), pp. 153-184; y Luis Gómez Canseco, "Desde los márgenes: Cervantes cautivo y Sancho renegado", en Heterodoxia, marginalidad y maravilla en los Siglos de Oro, coord. Jaime Olmedo Ramos y Laura Puerto Moro; dir. José María Díez Borque, Madrid, Visor Libros, 2016, pp. 85-97.

15 Miguel de Cervantes, op. cit., p. 544.

16 Miguel de Cervantes, op. cit., pp. 484-487.

17 Miguel de Cervantes, op. cit., pp. 454-458.

18 Para la pervivencia de Apuleyo en Cervantes, véase: Francisco J. Escobar, El asno de oro (Medina del Campo, 1543), Méjico, Frente de Afirmación Hispanista, A. C., en prensa; e id., "El asno de oro»: un viaje de metamorfosis hacia Cervantes, Lope, Góngora y Quevedo, Méjico, Frente de Afirmación Hispanista, A. C., en prensa.

19 Miguel de Cervantes, op. cit., p. 492. 
tivo $^{20}$; de esta manera, los interlocutores escucharán con atención un "discurso verdadero, a quien podría ser que no llegasen los mentirosos que con curioso y pensado artificio suelen componerse." ${ }^{21}$, palabras que traen a la memoria, a efectos de soldadesca, el calificativo "artificioso" por Cervantes aplicado a Bartolomé de Torres Naharro, autor de la Propalladia, evocada en el Canto de Caliope de La Galatea (cf. infra) ${ }^{22}$.

\section{APOTEGMAS PARA UNA ÉPICA NOVELESCA HUMANIZADA}

Como acabamos de comprobar, Rufo, en su prólogo al lector de Apotegmas, viene a bosquejar y esbozar su poética narrativa en concordia con una tentativa de épica novelesca humanizada propuesta en La Austríada, que caló también en la historia del cautivo de Cervantes. Por esta razón, no es de extrañar en ambas obras de Rufo una palmaria inclinación por la agudeza conceptual y el sabor paremiológico, por ejemplo en Apot. 217²3, con paralelo textual al decir de Sancho Panza en Quijote, I, 25 $5^{24}$, el arte de la memoria y la tradición oral, con cuentos tradicionales y folclóricos al fondo ${ }^{25}$, la cultura popular y la etnografía, la filosofía vulgar y la vida coti-

20 Cf.: "Fue común opinión que no se habían de encerrar los nuestros en la Goleta [...]; y los que esto dicen hablan de lejos y con poco experiencia de casos semejantes;" (Miguel de Cervantes, op. cit., pp. 500-501); incluso la opinión o perspectiva personal del cautivo puede llegar a confluir con la de otros: "Pero a muchos les pareció y así me pareció a mí, que fue particular gracia y merced que el cielo hizo a España en permitir que se asolase aquella oficina y capa de maldades [...]" (Cervantes, op. cit., p. 501); para otros pormenores sobre La Goleta y el principio de imitación cervantino, véase Jesús Ponce, La imitación áurea (Cervantes, Quevedo, Góngora), París, Éditions Hispaniques, 2016.

21 Miguel de Cervantes, op. cit., p. 492.

22 Miguel de Cervantes, op. cit., p. 361.

23 Cf:: "A un avariento dijo: "Vuestra bolsa tiene boca de infierno, porque en entrando el dinero en ella, nulla est redemptio»" (Juan Rufo, op. cit., p. 83).

24 En concreto, tras una alusión a la conocida pérdida del asno: “-"Quien ha infierno -respondió Sancho- nula es retencio», según he oído decir [...]” (Miguel de Cervantes, op. cit., p. 308).

25 Véanse al respecto, con especial atención a Rufo, los estudios de Maxime Chevalier: Cuentecillos tradicionales en la España del Siglo de Oro, Madrid, Gredos, 1975; Folklore y literatura: El cuento oral en el Siglo de Oro, Barcelona, Crítica, 1978; Cuen- 
diana, además de su interés por la etología y el comportamiento humano, todo ello revestido de un especial énfasis por el cuidado de la forma hasta el punto de evitar "la aspereza de los sonidos" en Apot. 63 ("Abogado del oído”); es decir, como habían procedido fray Luis de León, Fernando de Herrera o Mateo Alemán, lecturas del propio Cervantes.

A modo de correspondencia, el autor del Quijote se decantó más bien por el cuento de arquetipo popular y la paremiología verdadera, con glosa incluida, en el discurso de aliento épico-novelesco por parte del padre del cautivo $^{26}$, o sea, un vector medular que habrá de reaparecer como cierre del discurso de su vida en calidad de anagnórisis, con resonancias al tiempo de la tradición paremiológica de Rufo y Melchor de Santa Cruz, pero también atendiendo a la técnica de la glosa del refrán desde el paradigma conceptual de Hernán Núñez al científico-académico de Juan de Mal Lara, en las fronteras del humanismo tanto salmantino como hispalense. No obstante, esta metodología dual entre la tonalidad épico-novelesca y el sabor paremiológico, tan grata a Rufo, la vuelve a recuperar el cautivo cervantino en el "discurso de su vida" cuando viene a referir el catálogo de víctimas de guerra, con un tono truculento más humanizado respecto al aire épico de Lucano, identificable en el Jurado de Córdoba tras la senda de Juan de Mena y su Laberinto de Fortuna.

En otras palabras, tanto Rufo como Cervantes atendieron a un meditado maridaje de tonalidad épico-novelesca y sabor paremiológico, en el que

tos españoles de los siglos XVI y XVII, Madrid, Taurus, 1982; Tipos cómicos y folklore (siglos XVI-XVII), Madrid, EDI-6, 1982; Cuentos folklóricos en la España del Siglo de Oro, Barcelona, Crítica, 1983; y Cuento tradicional, cultura, literatura, siglos XVIXIX, Salamanca, Ediciones de la Universidad, 1999. Para el caso concreto de la historia cervantina y su filiación para con el cuento tradicional: Alfred Rodríguez y M. ${ }^{a}$ Dolores Velázquez, "El fondo tradicional del cuento del cautivo", Rilce. Revista de filología hispánica, 3.2 (1987), pp. 253-259.

26 Cf.: “-Hay un refrán en nuestra España, a mi parecer muy verdadero, como todos los son, por ser sentencias breves sacadas de la luenga y discreta experiencia; [...] "Iglesia o mar o casa real», como si más claramente dijera: 'Quien quisiere valer y ser rico siga o a la Iglesia o navegue, ejercitando el arte de la mercancía, o entre a servir a los reyes en sus casas'; porque dicen: «Más vale migaja de rey que merced de señor»; [...] Digo esto porque querría y es mi voluntad que uno de vosotros siguiese las letras, el otro la mercancía, y el otro sirviese al rey en la guerra, pues es dificultoso entrar a servirle en su casa; que ya que la guerra no dé muchas riquezas, suele dar mucho valor y mucha fama" (Miguel de Cervantes, op. cit., p. 494). 
no faltó la retractación de Lucano, con "refrán castellano" incluido ${ }^{27}$. Con todo, no estamos ante un caso excepcional, o hápax, en el que Cervantes decidió seguir los pasos de Rufo como lector de La Farsalia, aunque con una voluntad de emulación, según refleja el pasaje en el que el cautivo, o, si se quiere, Cervantes en calidad de autor caché en las lábiles fronteras entre la realidad y la ficción, viene a relatar detenidamente los avatares de su esclavitud en los baños de $\operatorname{Argel}^{28}$. De hecho, el pasaje atesora y desprende a las claras un notable tono truculento a la manera de Lucano, aunque, una vez más, revestido de una pátina más humanizada, si cabe, en la que se trasluce el apunte al amo entre la prisión épico-novelesca y la formalización autobiográfica de filiación picaresca, que habrá de dar paso, claro está, a la historia del "soldado español llamado tal de Saavedra"29.

Es decir, en consonancia con este tono sostenido paremiológico como bajo continuo u ostinato, Cervantes abogó por una meditada retractación respecto al sabor épico de Lucano en La Austríada de Rufo, como hiciera también con anterioridad Juan de Mena en el Laberinto de Fortuna al hilo

27 Cf.: “-[A Pagán de Oria, caballero del hábito de San Juan] los cuales alárabes le cortaron la cabeza y se la trajeron al general de la armada turquesca, el cual cumplió con ellos nuestro refrán castellano, que «aunque la traición aplace, el traidor se aborrece»." (Cervantes, op. cit., p. 502); como tampoco está ausente cierta crudeza truculenta y terrible crueldad en el siguiente fragmento: "-[Mi amo] Cada día ahorcaba el suyo, [a un esclavo] empalaba a éste, desorejaba aquél, y esto, por tan poca ocasión, y tan sin ella, que los turcos conocían que lo hacía no más de por hacerlo y por ser natural condición suya ser homicida de todo el género humano" (Cervantes, op. cit., p. 507).

28 Véanse sobre este particular: M. Antonia Garcés, Cervantes en Argel: historia de un cautivo, Madrid, Editorial Gredos, 2005; R. T. C. Goodwin, "Origins of the Novel in Cervantes's «Información de Argel»", Bulletin of Hispanic Studies, 83.4 (2006), pp. 317-337; M. a Rocío Periánez Gómez y Felicísimo García Barriga, "Cervantes, un cautivo entre cautivos: el problema del cautiverio de África en la Espańa del Siglo de Oro", en XXXIV Coloquios históricos de Extremadura. Dedicado a la memoria de Don Miguel de Cervantes en el IV centenario del "Quijote». Trujillo, 19-25 de septiembre de 2005, Trujillo, C. I. T. Trujillo, 2006, pp. 567-594; Maximiliano Barrio, "El corso y el cautiverio en tiempos de Cervantes", Investigaciones históricas. Época moderna y contemporánea, 26 (2006), pp. 81-114; Natalio Ohanna, "Cervantes, los musulmanes nuevos y la información de Argel”, Anales cervantinos, 41 (2009), pp. 267-284; y Mar Martínez Góngora, "El Magreb, pluralidad y memoria: Cervantes y las crónicas de Berbería en "La historia del cautivo"”, Cervantes. Bulletin of the Cervantes Society of America, 37.2 (2017), pp. 35-67.

29 Miguel de Cervantes, op. cit., p. 507. 
de episodios como el de la maga de Valladolid, en paralelo imitativo al bien conocido de Ericto de La Farsalia. Del mismo modo, en la historia del cautivo, cuando Agi Morato comprende la traición y conversión de su hija Zoraida ${ }^{30}$, se comporta de una forma desmesurada conforme a este fuste patético y truculento reconocible en Lucano, con resonancias a su vez en Rufo. Al tiempo, su actitud, al límite de las complejas pasiones humanas, denota una consciente impregnación del aire de los romances ariostescos a efectos de estética literaria ${ }^{31}$. Por lo demás, Cervantes a buen seguro había detectado en Rufo su atinado gusto por Lucano, del que se acabaría alejando como modelo en aras de una fórmula épico-novelesca más humanizada al servicio de su método consistente en "mostrar con propiedad un desatino"; por ejemplo en el canto XXIV de La Austríada (21, 24 y 39), dedicado a la preparación de la muerte de Alí-Bajá. No obstante, tales versos vienen a presentar visibles dosis de propaganda nacionalista, acordes con la tradición literaria no solo de la épica imperial en latín sino también de El laberinto de fortuna de Mena, como he señalado. Por ello no resultan anómalas, en fin, sus palmarias resonancias de $L a$ Farsalia, materializadas en una imaginería truculenta preñada de sangre y patetismo, con fuertes contrastes sensoriales y hasta apuntes al mundo abreviado del hombre, con paralelo ejemplar en Cervantes:

Dízese deste mismo, oh caso horrible, que ya cercano estando al trance fuerte, sobre un cristiano se arrojó terrible, que por muchas heridas sangre vierte; al cual con boca inmunda aborrecible,

30 En lo que atañe a dicho conflicto en la historia del cautivo, en virtud del arquetipo folclórico y a efectos de emociones humanas complejas: Alison Weber, "Padres e hijas: una lectura intertextual de "La historia del cautivo»", en Actas del II Coloquio Internacional de la Asociación de Cervantistas, pp. 425-432.

31 Así a propósito de Agi Morato, o sea, el padre de Zoraida: “-[...] Vimos sus obras, que eran arrancarse las barbas, mesarse los cabellos y arrastrarse por el suelo;" (Cervantes, op. cit., p. 532). Para la pervivencia de Ariosto véanse los siguientes estudios de Maxime Chevalier: L'Arioste en Espagne (1530-1650). Recherches sur l'influence $d u$ "Roland furieux», Burdeos, Institut d'Etudes Ibériques et Ibéro-Américaines de l'Université de Bordeaux, 1966; y Los temas ariostescos en el romancero y la poesía española del Siglo de Oro, Madrid, Castalia, 1968. 
los ojos sepultados ya en la muerte, las llagas muerde, y con la fría boca aquel cadáver mísero provoca ${ }^{32}$. [...]

Alí Baxá, que tal sucesso mira, siente en el alma un áspero despecho, brama como león, gime y suspira, animando su gente sin provecho; un rabioso dolor, ardiendo en ira, le rasga el coraçón dentro del pecho; color de sangre le salió a los ojos, que testimonio fue de sus enojos ${ }^{33}$. [...]

En algunas de Italia estar se vía un retrato del mundo abrevïado, donde el amargo llanto y alegría, el morir, el nacer anda mezclado; si en el fogón victoria se dezía, por el esquife turcos han saltado, la esperança a los unos alegrava, a los otros la muerte amenazava ${ }^{34}$.

Tampoco faltan, en suma, otras claras resonancias de La Farsalia en el pensamiento estético de Rufo que bien pudo reconocer Cervantes cuando estaba inmerso en la búsqueda e implementación creativa de un método épico-novelesco alentado por el principio de la verosimilitud ejemplar, como en Apot. 470, a propósito de Julio César ${ }^{35}$, pero sin desdeńo por parte de ambos autores de la tradición mitológica clásica ${ }^{36}$, a modo de mitología humanizada, con especial énfasis en el cabal conocimiento de las fábulas

32 Juan Rufo, op. cit., p. 840.

33 Juan Rufo, op. cit., p. 841.

34 Juan Rufo, op. cit., p. 843.

35 Juan Rufo, op. cit., p. 167.

36 Para el caso concreto de Rufo resulta de interés: Juan Luis Arcaz Pozo, "Notas sobre el uso del mito en La Austríada de Juan Rufo", en Kalòs kaì agazòs aner: didascálou parádeigma. Homenaje al profesor Juan Antonio López Férez, ed. Luis Miguel Pino Campos y Germán Santana Henríquez, Madrid, Ediciones Clásicas, 2013, pp. 8594. 
y otros elementos de la tradición grecorromana; son los casos de Ovidio y sus Metamorfosis (Apot. 556), Pitágoras y su silencio (Apot. 616), Penélope (Apot. 280) o Vulcano como dios herrero (Apot. 614), incluso al trasluz de señeros autores del Siglo de Oro asimilados por el autor de la historia del cautivo tales como el poeta y músico lusitano Jorge de Montemayor y su Fábula de Píramo y Tisbe (Apot. 185) ${ }^{37}$. En síntesis, como Rufo, aunque con las divergencias temático-conceptuales que iremos analizando progresivamente, Cervantes decidió decantarse por una retractación humanizada de la tradición clásica, esto es, de manera similar a otros referentes singulares de la época como Diego de Velázquez en calidad de lector tanto de las Metamorfosis de Ovidio como de las de Apuleyo, según tendremos la ocasión de comprobar al hilo de la "verdad del caso" del cautivo.

\section{Rufo y Cervantes en Lepanto: de la experiencia vital a la EXPRESIÓN ESTÉTICA}

A la vista de lo seńalado hasta el momento, tanto para Rufo como para Cervantes, la experiencia de la vida en calidad de obra de arte hace que el resultado estético resulte más verosímil en el horizonte de expectativas del lector $^{38}$. Por esta razón, ambos escritores llegaron incluso a optar por la técnica de autorrepresentación en la ficción, en una visible marca autorial o, si se quiere, perfil de autor (sphragis) ${ }^{39}$. En cuanto a la recreación como personaje actante por parte del Jurado de Córdoba, cabe recordar, en los Apotegmas, la carta a su hijo, el pintor Luis Rufo, del que se hace también su representación ficticia y retrato literario por su notable memoria (653), por haberse quedado dormido en una reunión $(654,688)$, por el hecho de no haber logrado el mecenazgo esperado (682) o hasta por la confirmación

37 Juan Rufo, op. cit., pp. 194-195, 214, 105-106, 213 y 72, respectivamente.

38 Un adelanto conceptual aplicado al humanismo hispalense, con resonancias en Cervantes y su "mostrar con propiedad un desatino", ofrezco en Vidas de arte en el humanismo hispalense. De Nebrija a Góngora, pról. Jaime Garau, Méjico, Frente de Afirmación Hispanista, A. C., 2018.

39 En lo que a Rufo se refiere, véase Pedro Ruiz Pérez, "De la oralidad a la literatura: la formulación autobiográfica de los Apotegmas de Juan Rufo", Boletín de la Real Academia Española, 78 (1998), pp. 401-426. 
de la mano del Cardenal Quiroga (689) ${ }^{40}$. Asimismo, en armonía con el bosquejo estético de su bisoño vástago, Rufo decidió retratarse, ora la pluma, ora el pincel, en virtud de sus apotegmas manuscritos (684) o por sus cualidades como poeta de repente (658) y su producción estética a propósito de un soneto y otras composiciones $(577)^{41}$. Además se detecta igualmente su recuerdo, o anámnesis, de las guerras de Flandes (570), su actitud de desidia y pereza (574), su aspecto de delgadez a modo de pictórica prosopografía (91), su precario estatus económico debido a una acuciante y acerba pobreza $(91,356,376,536,574,602)$, pero también su perfil “oleado" (19, 429), viejo $(362,381)$, enfermo $(380)$ y hasta con gota $(572)^{42}$.

Es más, no cabe pasar por alto en dicha autorrepresentación, tan cervantina por otra parte hasta culminar como acmé o floruit en El viaje del Parnaso, sabrosas anécdotas, circunstancias y azarosos avatares de su vida al hilo del ayo de un noble (77) o su prolongada ausencia en el entorno personal y profesional acostumbrado durante una década (14), sus reiteradas estancias en ciudades como Sevilla (527) y Alcalá de Henares (453), o su encuentro tan singular con Felipe II (601) ${ }^{43}$. A este boceto personal, como perfil autobiográfico, resulta necesario ańadir la relación intertextual planteada por el Jurado cordobés entre sus obras, con autorreferencialidad incluida, una vez más, de manera que La Austríada viene a estar bien presente en los Apotegmas 223, 299, 356, 376 ó 476 ${ }^{44}$; o sea, de modo similar a los vínculos intrínsecos entre las novelas cervantinas, como es el caso de El coloquio de los perros, novela en la que se menciona por cierto la Academia imitatoria en la que participó Rufo y con crítica de paso a los moriscos, o Rinconete y Cortadillo, historia evocada en el Quijote junto a la de El curioso impertinente ${ }^{45}$.

En cualquier caso, asistimos a un universo e imaginario creativo en calidad de palimpsesto o palingénesis entre la realidad y la ficción de Le-

40 Juan Rufo, op. cit., pp. 226-227, 227, 236-237, 235 y 237.

41 Juan Rufo, op. cit., pp. 235, 228 y 201.

42 Juan Rufo, op. cit., pp. 199, 200, 44-45, 130-131, 136-137, 187, 200, 209, 21, $152,132,138$ y 200.

43 Juan Rufo, op. cit., pp. 39, 20, 184, 161 y 209.

44 Juan Rufo, op. cit., pp. 84-85, 112, 130-131, 136-137 y 169.

45 Para las analogías y divergencias de esta novela respecto a la historia del cautivo véase Robert M. Flores, " $\mathrm{El}$ curioso impertinente» $\mathrm{y}$ "El capitán cautivo», novelas ni sueltas ni pegadizas", Cervantes. Bulletin of the Cervantes Society of America, 20.1 (2000), pp. 79-98. 
panto $^{46}$, con cárceles de por medio, compartido por Rufo y Cervantes, en el que se enaltecen personajes tan representativos como Marco Antonio Colonna, rememorado no solo en La Austriada ${ }^{47}$ sino también en los Apotegmas, en correspondencia con su hijo Ascanio Colonna $(453)^{48}$, es decir el dedicatario de La Galatea, con quien llegó a cartearse el Jurado de Córdoba, al igual que fray Luis de León, Luis Gálvez de Montalvo, Luis de Vargas o el conde de Salinas, entre otros nombres representativos de la Edad de Oro ${ }^{49}$. Pero sin duda acaso la representación del soldado Saavedra en la historia del cautivo desde el prisma estético de Cervantes sea el elemento temático que mejor venga a entroncar con esta marcada inclinación literaria de Rufo por la autorreferencialidad en las fronteras entre la realidad y la ficción. Pasemos a verlo.

\section{El soldado SaAvedra en los "baños de Argel" (con Arnaute MAMÍ AL FONDO)}

En esta confluencia de historia verdadera y fingida, con Lepanto como colonna sonora, por parte de Rufo, Cervantes se propuso ofrecer en la his-

46 Sobre la batalla de Lepanto y sus principales protagonistas: José M. ${ }^{a}$ March, La Batalla de Lepanto y Don Luis de Requeséns, Lugarteniente General de la Mar: con nuevos documentos históricos ..., Madrid, Ministerio de Asuntos Exteriores, Sección de Relaciones Culturales, 1944; Luciano Serrano, España en Lepanto, Madrid, Editora Nacional, 1971; Jean Dumont, Lepanto, la historia oculta, Madrid, Encuentro, 1999; Ramiro Ponce del Río, Lepanto, la batalla inacabada, pról. José Enrique Ruiz-Domènec, Barcelona, Dédalo, 2006; Manuel Rivero Rodríguez, La batalla de Lepanto: cruzada, guerra santa e identidad confesional, Madrid, Sílex, 2008; Agustín Ramón Rodríguez González, Lepanto: la batalla que salvó a Europa, Madrid, Sekotia, 2010; Alessandro Barbero, Lepanto: la batalla de los tres imperios, trad. Teófilo de Lozoya y Juan Rabasseda, Barcelona, Pasado \& Presente, 2011; y Víctor Mínguez, Infierno y gloria en el mar: los Habsburgo y el imaginario artístico de Lepanto (14301700), Castelló de la Plana, Universitat Jaume I, 2017.

47 Así en XX, 32, XXII, 121 ó XXIII, 95 (Juan Rufo, op. cit., pp. 675, 761 y 809).

48 Apotegma ya apuntado a propósito de Alcalá de Henares (Rufo, op. cit., p. 161).

49 Sobre este particular: Patricia Marín Cepeda, "Poesía, corte y epistolaridad entre España e Italia: cuarenta y seis cartas inéditas de Diego de Silva y Mendoza, Conde de Salinas, con el cardenal Ascanio Colonna (1560-1608)", Artifara. Revista de lenguas $y$ literaturas ibéricas y latinoamericanas, 15 (2015), pp. 1-2. 
toria del cautivo cuidadas notas de etnografía a propósito de los "baños" de Argel, con rescate incluido y su recuerdo a Onofre Exarque, o sea, el fautor de una de sus tentativas de fuga, cuando los cautivos estaban preparando la huida en barca $^{50}$. Se trata, en efecto, de la remembranza o evocación de Arnaute Mamí, al igual que sucede en el relato de Timbrio en La Galatea con "cosarios" en calidad de personajes actantes ${ }^{51}$, de quien

50 Cf.: “-[...] y yo cupe a un renegado veneciano, que, siendo grumete de una nave, le cautivó el Uchalí, y le quiso tanto, que fue uno de los más regalados garzones suyos, y él vino a ser el más cruel renegado que jamás se ha visto. Llamábase Azán Agá, y llegó a ser muy rico y a ser rey de Argel [...]. Con esto entretenía la vida, encerrado en una prisión o casa que los turcos llaman baño, donde encierran los cautivos cristianos. [...] Pusiéronme una cadena, más por señal de rescate que por guardarme con ella, y así pasaba la vida en aquel baño [...]. Solo libró bien con él un soldado español llamado tal de Saavedra, el cual, con haber hecho cosas que quedarán en la memoria de aquellas gentes por muchos años, y todas por alcanzar libertad, jamás le dio palo, ni se lo mandó dar, ni le dijo mala palabra; [... y si no fuera porque el tiempo no da lugar, yo dijera ahora algo de lo que este soldado hizo, que fuera parte para entreteneros y admiraros harto mejor que con el cuento de mi historia" (Miguel de Cervantes, op. cit., pp. 506-507); también: “-Dimos luego quinientos escudos al renegado para comprar la barca; con ochocientos me rescaté yo, dando el dinero a un mercader valenciano que a la sazón se hallaba en Argel, el cual me rescató del rey, tomándome sobre su palabra, dándola de que con el primer bajel que viniese de Valencia pagaría mi rescate; porque si luego diera el dinero, fuera dar sospechas al rey que había muchos días que mi rescate estaba en Argel y que el mercader por sus granjerías, lo había callado." (Cervantes, op. cit., p. 516). Sobre estos "regalados garzones" y otros significativos referentes cervantinos de la historia del cautivo como los higos, a los que aludo más abajo: Juan Diego Vila, "Tráfico de higos, regalados garzones y contracultura: en torno a los silencios y mentiras del Capitán cautivo", en Peregrinamente peregrinos. Actas del V Congreso Internacional de la Asociación de Cervantistas. Lisboa, Fundaçâo Calouste Gulbenkian, 1-5 septiembre 2003, coord. Alicia Villar Lecumberri, Alcalá de Henares, Asociación de Cervantistas, 2004, vol. 2, pp. 1833-1864. Por último, para el rescate como hecho histórico en época de Cervantes, con Valencia al fondo: Francisco José Sanchís Moreno, "El rescate de cautivos cristianos en Argel desde puertos valencianos: la embarcación en favor de Miguel de Cervantes", en Homenaje a Antonio Matilla Tascón, coord. José Andrés Casquero Fernández, Zamora, Diputación Provincial - Instituto de Estudios Zamoranos «Florián de Ocampo", 2002, pp. 601-614; Juan Corbalán de Celis y Durán, "El rescate de los cautivos valencianos en tiempos de Cervantes", Boletin de la Sociedad Castellonense de Cultura, 84.1-2 (2008), pp. 179-191; y Jesús Villalmanzo Cameno, "Cervantes, fray Juan Gil y los mercaderes valencianos”, Anales cervantinos, 48 (2016), pp. 53-101.

51 En concreto, en el libro V (Miguel de Cervantes, op. cit., p. 299). 
el cautivo se hace pasar por esclavo suyo, de nuevo en una estrecha relación entre amo y sirviente ${ }^{52}$.

Pues bien, en dicho contexto narrativo, no faltan igualmente, en las fronteras entre realidad y ficcionalización épico-novelesca, las alusiones a la Liga Santa contra el turco, la aretalogía de D. Juan de Austria ${ }^{53}$, la carta de rescate por parte de Cervantes ${ }^{54}$, su especial atención al "capitán don Álvaro de Bazán, marqués de Santa Cruz" ${ }^{55}$ y, claro está, el catálogo de héroes prisioneros presentados como víctimas del enemigo infiel mediante sugerentes construcciones anafórico-paralelísticas a modo de ritmo interior narrativo ${ }^{56}$. No obstante, tiene su correspondencia retórico-conceptual en el de La Austríada (canto XXIV), más allá del diálogo intertextual respecto a Apotegmas a propósito de "El de Santa Cruz" (49)57, "Don

52 A propósito de esta relación entre dominadores y dominados, con Arnaute Mamí bien presente, cf.: "No se pasaron quince días, cuando ya nuestro renegado tenía comprada una muy barca, capaz de más de treinta personas; [...] quiso hacer, como hizo, un viaje a un lugar que se llamaba Sargel, que está treinta leguas de Argel hacia la parte de Orán, en el cual hay mucha contratación de higos pasos. Dos o tres veces hizo este viaje, en compañía del tagarino que había dicho. [...] Digo, pues, que cada vez que pasaba con su barca daba fondo en una caleta que estaba no dos tiros de ballesta del jardín donde Zoraida esperaba [...]; las moras no se dejan ver de ningún moro ni turco, si no es que su marido o su padre se lo manden. De cristianos cautivos se dejan tratar y comunicar aún más de aquello que sería razonable [...]; y la primera persona con quien encontré fue con su padre [...]; me preguntó que qué buscaba en aquel su jardín y de quién era. Respondile que era esclavo de Arnaute Mamí (y esto, porque sabía yo por muy cierto que era un grandísimo amigo suyo) y que buscaba de todas yerbas para hacer ensalada. Preguntome, por el consiguiente, si era hombre de rescate o no y que cuánto pedía mi amo por mí [...]. Así como ella llegó [Zoraida al jardín], le dijo su padre [Agi Morato] en su lengua cómo yo era cautivo de su amigo Arnaute Mamí y que venía a buscar ensalada." (Cervantes, $o p$. cit., pp. 517-521).

53 Miguel de Cervantes, op. cit., pp. 496-497 y 499-500.

54 " $-[\ldots . .$.$] En todos estos trances andaba yo al remo, sin esperanza de libertad alguna, a$ lo menos, no esperaba tenerla por rescate, porque tenía determinado de no escribir las nuevas de mi desgracia a mi padre." (Cervantes, op. cit., p. 500).

55 Miguel de Cervantes, op. cit., p. 499.

56 "Ninguno cautivaron sano de trecientos que quedaron vivos. [...] Cautivaron a don Pedro Puertocarrero [...]; cautivaron ansimesmo al general del fuerte, que se llamaba Gabrio Cervellón [...]" (Miguel de Cervantes, op. cit., p. 501).

57 Juan Rufo, op. cit., p. 844. 
Alonso Baçán, hermano digno / del marqués y por él diciplinado” (55) y, por supuesto, en un lugar excepcional "Don Juan de Austria" (69) hijastro de Carlos V, con apunte cervantino al hecho de "conservar la memoria de haberlo ganado la felicísima del invictísimo Carlos Quinto"60. Por lo demás, se trata de un dato este último que trae a la memoria no solo la historia del cautivo sino también el conocido prólogo de las $\mathrm{No-}$ velas ejemplares, en un contexto político-sociocultural que conllevaba la vuelta a una nueva Edad de Oro con don Juan de Austria en calidad de adalid y estandarte principal, una vez frustrada la esperanza del malogrado príncipe Carlos, tan aclamado, en un principio al menos, en el entorno humanístico hispalense de Juan de Mal Lara, Fernando de Herrera, Cristóbal Mosquera de Figueroa o Mateo Vázquez de Leca, secretario de Felipe II (vid. infra) ${ }^{61}$.

Sea como fuere, en la intersección de códigos brindada entre realidad y ficción en la historia del cautivo, el protagonista respalda la legitimidad autorial de los dos sonetos de don Pedro de Aguilar, ante la escucha atenta y acuidad de don Fernando, su hermano, para proseguir el "cuento" ${ }^{2}$. Lo hace, no obstante, conforme al principio cervantino de unidad y variedad, prosa y poesía, esto es, siguiendo el prosímetro implementado por Jacopo Sannazaro en La Arcadia, con notas de etnografía cercanas a la filosofía

58 Juan Rufo, op. cit., p. 845; cf. Apot. 74 (Rufo, op. cit., p. 38).

59 Juan Rufo, op. cit., p. 846.

60 Miguel de Cervantes, op. cit., p. 501.

61 Para otros pormenores sobre dicho entorno humanístico pueden leerse los estudios introductorios a mi edición de la obra poética de Mal Lara, esto es, Hércules animoso, La Psyche y Poesía dispersa (vernácula y latina), editada en México por el Frente de Afirmación Hispanista, A. C., 2015.

62 Cf.: "-Desa manera le sé yo -dijo el cautivo. [...]

No parecieron mal los sonetos, y el cautivo se alegró con las nuevas que de su camarada le dieron, y prosiguiendo su cuento, dijo:

-Rendidos, pues, la Goleta y el fuerte, los turcos dieron orden de desmantelar la Goleta [...]; y de allí a pocos meses murió mi amo el Uchalí, al cual llamaban Uchalí Fartax, que quiere decir en lengua turquesca 'el renegado tińoso', porque lo era, y es costumbre entre los turcos ponerse nombres de alguna falta que tengan o de alguna virtud que en ellos haya; y esto es porque no hay entre ellos sino cuatro apellidos de linajes, que decienden de la casa otomana, y los demás, como tengo dicho, toman nombre y apellido ya de las tachas del cuerpo, y ya de las virtudes del ánimo” (Miguel de Cervantes, op. cit., pp. 504-505). 
vulgar en la línea conceptual de Mal Lara, con la que llega a entroncar Rufo; sin olvidar tampoco la presencia del amo a quien sirve el cautivo, con puntos de encuentro, en fin, respecto al apuleyanismo hispalense y la filiación picaresca, o lo que es lo mismo, Cervantes en Sevilla y la Sevilla de Cervantes $^{63}$. Asimismo, en esta reflexiva confluencia de historia verdadera y fingida se produce la ruptura de la cronología interna en el discurso de la vida del cautivo, habida cuenta de que Uchalí fallece en 1587, no a los pocos meses, mientras que en 1581 había atacado Argel. Esto es, el subtema o motivo temático viene a entroncar, en su esencia estética, con la historia de vida de amos y cautivos marginados en esta formalización épico-novelesca propuesta, complementaria por lo demás a una nueva vía de indagación estética dada por otra picaresca cervantina, en tanto que resultan bien visibles las calas de etnografía al hilo de los "bańos” de Argel, de eminente sabor cervantino, donde esperan los cristianos nuevas de su rescate $^{64}$, es decir como le sucedió al autor del Quijote en su trayectoria vital y personal.

En cualquier caso, el cautivo, prosiguiendo el relato o "cuento" con su estancia en los baños de Argel, decide finalmente referir el caso del soldado espańol Saavedra, o sea, Cervantes representado en la ficción, con deseo de "alcanzar la libertad", en un paralelo textual respecto al Prólogo de las Novelas ejemplares, si bien de él no puede narrar el discurso de su vida ("cuento de mi historia") "porque el tiempo no ha lugar"65, en una característica suspensión narrativa practicada con frecuencia por el autor del Quijote. De hecho, tiene su continuación en I, 41 ("Donde todavía prosigue el cautivo su suceso"), con alusiones a su vez al viaje peregrino del renegado y el tagarino ${ }^{66}$, el cautivo en el jardín de Zoraida y por supuesto las sugerentes costumbres de las doncellas moras, como en Los baños de Argel y El amante liberal.

En otras palabras, la historia del cautivo viene a reflejar, bajo el cromático arrope de la ficción, la vivencia y experiencia vital de Cervantes en Lepanto, al igual que también le había sucedido a Rufo, quien debió

63 Véase Francisco J. Escobar, Vidas de arte en el humanismo hispalense, pp. 55-64.

64 Miguel de Cervantes, op. cit., pp. 506-507.

65 Miguel de Cervantes, op. cit., pp. 507-508.

$66 \mathrm{O}$ lo que es lo mismo, estando siempre bien presente la pareja cervantina como recurso medular de su concepto novelístico dialógico. 
servirle de lúcido y lucido espejo literario en su progresivo camino de indagación creativa. No obstante, en la historia cervantina, el cautivo decide "seguir el ejercicio de las armas, sirviendo en él a Dios y a mi rey" ${ }^{67}$, con promesa a los circunstantes de relatar su vida con concisión (“y lo que en este discurso de tiempo he pasado lo diré brevemente"), entre apuntes a la Liga Santa contra el turco, con don Juan de Austria al fondo, y en un recuerdo, una vez más, al prólogo de las Novelas ejemplares ("Digo, en fin, que yo me hallé en aquella felicísima jornada, ya hecho capitán de infantería", o "en aquel día, digo, donde quedó el orgullo y soberbia otomana quebrantada" $)^{68}$, en el que se identifica una consciente modulación hacia el tema del cautiverio, con cadenas de por medio ${ }^{69}$ : "entre tantos venturosos como allí hubo [...], yo sólo fui el desdichado"; "me vi aquella noche que siguió a tan famoso día con cadenas a los pies y esposas a las manos.", "y fue desta suerte: que habiendo el Uchalí, rey de Argel, atrevido y venturoso cosario [...]."70.

El cautivo relata, por último, el discurso de su vida como si fuera verdad, o sea en un locus communis estético-conceptual respecto al relato de Timbrio, en la historia de los dos amigos (vid. infra), y los "cosarios" de Arnaut Mamí, apodado el Albanés. No obstante, los “cosarios” llegan a embestir contra la galera y el protagonista acabará siendo apresado ${ }^{71}$. Asimismo, apuntadas las circunstancias contextuales de sabor histórico, viene a reiterar el protagonista las acerbas y atribuladas penurias de su

67 Miguel de Cervantes, op. cit., p. 495.

68 Miguel de Cervantes, op. cit., p. 497.

69 Véase: Aldo Ruffinatto, "Cautivos en cadena (Los cautivos de Cervantes entre vida y creación)", en Tus obras los rincones de la tierra descubren. Actas del VI Congreso Internacional de la Asociación de Cervantistas, coord. Alexia Dotras Bravo, José Manuel Lucía Megías, Elisabet Magro García y José Montero Reguera, Alcalá de Henares, Centro de Estudios Cervantinos, 2008, pp. 657-672; también del mismo autor: Dedicado a Cervantes, Madrid, Sial, 2015.

70 Miguel de Cervantes, op. cit., p. 497.

71 Como se recordará: “y, así, me hallé solo entre mis enemigos, a quien no pude resistir, por ser tantos: en fin me rindieron lleno de heridas [...]; vine yo a quedar cautivo en su poder [de Uchalí], y solo fui el triste entre tantos alegres y el cautivo entre tantos libres, porque fueron quince mil cristianos los que aquel día alcanzaron la deseada libertad, que todos venían al remo en la turquesca armada. Lleváronme a Constantinopla, donde el Gran Turco Selín hizo general de la mar a mi amo, porque había hecho su deber en la batalla [...]" (Miguel de Cervantes, op. cit., p. 498). 
cautiverio, "sin esperanza de libertad", en el discurso de su vida. Asistimos, claro está, a una nueva correspondencia entre realidad y ficción respecto a la carta de rescate por parte de Cervantes en la que se ponen de relieve, en fin, las tomas de galeras en un relato pormenorizado y revestido de suspense épico-novelesco ("En este viaje se tomó la galera que se llamaba $L a$ Presa, de quien era capitán un hijo de aquel famoso cosario Barbarroja”) ${ }^{72}$.

5. Cervantes intérprete de Claves épiCAS y PAREMiológicas: INTERSECCIÓN DE CÓDIGOS GENÉRICOS

Como estamos viendo, en su paulatino proceso de exploración creativa, Cervantes fue un avisado intérprete de las claves épico-paremiológicas de Rufo, en la propia intersección de códigos genéricos propuesta por este en sus dos obras. En cuanto a las claves épicas en concreto, La Austríada, obra que relata, como es sabido, los hechos y sucesos desde la sublevación morisca de las Alpujarras hasta la batalla de Lepanto ${ }^{73}$, se trata de un poema celebrado por el cura, entre "los mejores que en verso heroico en lengua castellana están escritos”, en el donoso escrutinio con historia abreviada pastoril previa y autorrepresentación autorial a propósito de La Galatea (Quijote, I, 6) ${ }^{74}$, que resulta además consonante con el temperamentum en la historia del cautivo entre su pátina épico-novelesca y las huellas de aliento pastoril, dado que "un pastor había apellidado al arma"75; es decir, en correspondencia con la épica novelesca hispalense y su apuleyanismo de fondo, así el Hércules animoso y La Psyche de Juan de Mal Lara, cuestión sobre la que volveré más adelante.

Por lo demás, en la historia cervantina, los cristianos, al llegar a VélezMálaga $^{76}$, buscan "algunas cabañas de pastores", hasta el punto de que acabarán divisando "al pie de un alcornoque un pastor mozo" con gana-

72 Miguel de Cervantes, op. cit., p. 499.

73 Con las implicaciones estético-conceptuales aludidas ya en el Prólogo de las Novelas ejemplares.

74 Miguel de Cervantes, op. cit., p. 94.

75 Miguel de Cervantes, op. cit., p. 537.

76 Miguel de Cervantes, op. cit., p. 537. 
$\mathrm{do}^{77}$. No obstante, en dicho contexto poliédrico, cuando este descubre a los cristianos en "hábito moro" piensa que eran infieles, lo que le llevará a manifestar con toque paródico, en una armonización de modalidades genéricas por parte del autor del Quijote: "-iMoros, moros hay en la tierra! ¡Moros, moros! ¡Arma, arma!”78. O sea, Cervantes insiste en el hecho sorpresivo, a modo de qui pro quo, tan teatral, de que "un pastor había apellidado al arma" conforme al canon de una épica humanizada, con un ápice por añadidura de donosa escenificación. Al tiempo, el cautivo, al divisar al pastor, deseaba "[...] comenzar a decirle mi suceso y de dónde veníamos y quién éramos" "79, en tanto que uno de los cristianos reconoce a su tío Pedro de Bustamante en una suerte de anagnórisis ${ }^{80}$. En cualquier caso, el recorrido, itinerario o trayecto desde Vélez-Málaga a la "ciudad de Granada" viene a realzar un enclave geográfico esencial en las narraciones moriscas, hasta el punto de constituir un símbolo ideológico significativo al final de la historia del cautivo, dado que el renegado acabará culminando su conversión espiritual en Granada ante la Inquisición ${ }^{81}$.

De otro lado, más allá del catálogo de personajes épicos recreado por Rufo en La Austriada, como El marqués de Santa Cruz (VIII), Sancho de Leiva (IX), don Antonio de Luna (X) o el duque de Sesa (XIV-XV) ${ }^{82}$, al igual que en la historia del cautivo ${ }^{83}$, en La Austríada tiene cabida la trama amorosa con la muerte de Abenhumeya y el alzamiento como rey de Abenabo (XIV), mientras que "Huzen, capitán turco, se enamora de

77 Miguel de Cervantes, op. cit., p. 536. Sobre las figuras marginales de pastores y cautivos en la poética cervantina: Antonio Rey Hazas, "Cervantes frente a Felipe II: pastores y cautivos contra la anexión de Portugal”, Príncipe de Viana. Anejo, 18 (2000), pp. 239-260.

78 Miguel de Cervantes, op. cit., p. 536.

79 Miguel de Cervantes, op. cit., p. 537.

80 Miguel de Cervantes, op. cit., p. 537; cf. asimismo: “[...] pero al renegado, Zoraida y a mí nos llevó el cristiano que vino con nosotros, y en casa de sus padres, que medianamente eran acomodados de los bienes de fortuna, y nos regalaron con tanto amor a su mismo hijo" (Cervantes, op. cit., p. 538).

81 Cf.: "Seis días estuvimos en Vélez, al cabo de los cuales el renegado, hecha su información de cuanto le convenía, se fue a la ciudad de Granada a reducirse por medio de la Santa Inquisición al gremio santísimo de la Iglesia” (Miguel de Cervantes, op. cit., pp. 538-539).

82 Quien acabará "provocando a batalla", como es sabido, a Abenabo en las Alpujarras. 83 Juan Rufo, op. cit., pp. 316, 346, 371, así como 491 y 520, respectivamente. 
Zara, y es causa de la muerte del reyezillo" y "Diego Alguacil, su primero enamorado, sale en compaña con su competidor" ${ }^{4}$. Se trata, en suma, de una trama y urdimbre épico-novelesca a partir de atractivas historias de cautivos en las que subyace sub cortice la exaltación propagandística de la batalla de Lepanto en consonancia con otros relatos afines, por ejemplo cuando el Duque de Sessa se enfrenta a Abenabo (XVI-XVII), "Selín junta poderosa armada; reforma a Pialí y haze general al turco Alí Baxá” (XIX) o es "sabido por Alí Baxá que Su Alteza se le cerca, determina en consejo salille al encuentro y dalle la batalla;" (XXII) ${ }^{85}$; en definitiva, al decir del propio Rufo (XXIV) y como prefiguración in nuce del enaltecimiento nacionalista de Cervantes en su experimental concepto épico-novelesco,

cuéntanse muchos casos dignos de memoria, y el glorioso sucesso en favor de los cristianos: muere Alí Baxá, y quedan sus hijos presos, con infinito número de muertos y captivos. Y, en efeto, se concluye la mayor hazaña de mar que por escripto ni relación se halla en la memoria de los hombres ${ }^{86}$.

Por otra parte, si bien pudo advertir y reconocer Cervantes durante su cautiva lectura de Rufo la presencia, vigencia e impregnación de la épica latina ${ }^{87}$, en castellano e italiana, por ejemplo Ariosto y el Orlando furioso, así como Luigi Tansillo y sus Lágrimas de San Pedro, o, desde otras hibridaciones y modalidades afines, los Dicta et facta de Valerio Máximo, con mirabilia en la historia del cautivo y contrahechos en el Quijote de 1605, e incluso la granada tradición propagandística mediante translatio studii desde Virgilio ${ }^{88}$ a Hernando de Acuña, este último con su soneto "Al Rey

84 Juan Rufo, op. cit., p. 491.

85 Juan Rufo, op. cit., pp. 547 y 578, así como 640 y 746.

86 Juan Rufo, op. cit., p. 838.

87 En la que no faltan, claro está, motivos y subtemas de la tradición clásica como el de la tempestad: Vicente Cristóbal López, “Tempestades épicas”, Cuadernos de investigación filológica, 14 (1988), pp. 125-148.

88 Para la pervivencia del poeta de Mantua en la producción estética de Rufo: Juan Luis Arcaz Pozo, "Virgilianismos en La Austriada de Juan Rufo", en Humanismo y pervivencia del mundo clásico. Homenaje al profesor Antonio Prieto. IV, coord. José M. ${ }^{a}$ Maestre Maestre, Joaquín Pascual Barea y Luis Charlo Brea, Madrid - Alcañiz, CSIC - Instituto de Estudios Humanísticos, 2008, vol. 1, pp. 91-100. 
Nuestro Señor", o sea Carlos V ("Un monarca, un imperio y una espada"), no cabe olvidar otro destacado pilar, no atendido suficientemente hasta el momento por parte de la crítica. Me refiero al granado contexto humanístico hispalense, en el que tanto interesó la heroica figura de don Juan de Austria, la Galera real y la batalla de Lepanto, que Rufo, como también Cervantes, llegó a conocer de primera mano; de esta manera, cabría ampliar miras y completar así esta pervivencia épica con otros modelos medulares como Fernando de Herrera y sus aires proféticos en la conocida canción a Lepanto dedicada a don Juan de Austria o el Vaticinio de Proteo de Cristóbal Mosquera de Figueroa en la Descripción de la Galera real de Juan de Mal Lara ${ }^{89}$. Mosquera, en concreto, poeta y vihuelista, fue allegado a Cervantes hasta el punto de proporcionarle trabajo como recaudador de la Armada Invencible, si bien participó además en la expedición a las Azores en calidad de Auditor General de la Armada, de la que fue cronista, y a la isla Terceira; igualmente mantuvo relación profesional con Alonso de Ercilla ${ }^{90}$, cuya tercera parte de la Araucana prologó, y con Álvaro de Bazán, primer marqués de Santa Cruz, a quien se refiere Rufo en Apot. $74^{91}$; incluso, en relación con nuestro objeto de estudio, redactó El conde Trivulcio (1586), publicándolo en 1596 bajo el título Elogio del excelentissimo señor Don Álvaro de Baçán, Marqués de Santa Cruz (1596). Por último, en este selecto elenco, Parnaso o república de las letras de clara tonalidad hispalense hay que recordar el tratado De la Filosofía de las armas y de su destreza y la agresión y defensa cristiana de Jerónimo de Ca-

89 Véase Francisco J. Escobar, "Una fuente desconocida para la Descripción de la Galera Real (con unos paralelos textuales en la obra de Cristóbal Mosquera de Figueroa y Juan de Mal Lara)", Nueva Revista de Filología Hispánica, 58.2 (2010), pp. 663689. Sobre los epigramas de la Descripción de la Galera Real: Rocío Carande Herrero, Mal-Lara y Lepanto: los epigramas latinos de la Galera Real de don Juan de Austria, pról. Juan Gil, Sevilla, Caja San Fernando, 1990.

90 En lo que hace al contrapunto estético-conceptual entre Ercilla y Rufo: Elizabeth B. Davis, "Escribir después de Ercilla: la codicia en La Austríada de Juan Rufo", en Actas del XII Congreso de la Asociación Internacional de Hispanistas, 21-26 de agosto de 1995, Birmingham. Estudios áureos I, coord. Jules Whicker, Birmingham, University of Birmingham, Department of Hispanic Studies, 1998, vol. 2, pp. 162-168.

91 Juan Rufo, op. cit., p. 38. 
rranza $(1582)^{92}$, autor elogiado por Cervantes en el Canto de Calíope de La Galatea ${ }^{93}$. De hecho, basta mencionar su afamado y esclarecido nombre a propósito del conocido episodio de los odres de sabor apuleyano y la parodia de la esgrima como remedo del combate épico-novelesco en el Quijote, antesala de la historia del cautivo. Por lo demás, fue buen amigo y compañero de los eruditos sevillanos mencionados y también, al igual que ellos, gran lector y hasta recreador de El asno de oro ${ }^{94}$.

Se trata de un entorno humanístico, en efecto, en el que se estaba cultivando a mediados del siglo XVI fórmulas híbridas de experimentación circunscritas al género épico-novelesco, con Lepanto al fondo a propósito de la Galera real de don Juan de Austria ${ }^{95}$, en armonía también con la compilación y glosa de refranes en virtud de una tradición paremiológica que viene a hermanar los lieux du savoir de Salamanca y Sevilla, dando como resultado una ambiciosa obra de cooperación académica y de equipo como la Filosofía vulgar de Mal Lara. Por ello, teniendo en cuenta esta distinguida

92 Con guińos y hasta tecnicismos o verba propria procedentes del arte de destreza como "tajo" y "estocada" (Apot. 581 y 492; Juan Rufo, op. cit., pp. 202 y 173).

93 Miguel de Cervantes, op. cit., p. 378.

94 Sobre Carranza y el entorno humanístico hispalense, con Cervantes, al fondo, véanse mis estudios: "Nouveaux renseignements sur Fernando de Herrera et l'Académie sévillane dans Philosophía de las armas, de Jerónimo de Carranza", en La Renaissance en Europe dans sa diversité. III. Circulation des hommes, des idées et des biens, héritages, ed. Lioudmila Chvedova, Michel Deshaies, Stanislaw Fiszer y Marie-Sol Ortola, Nancy, Université de Lorraine, Groupe "XVI et XVII siècles en Europe», 2015, pp. 289-303; "Dos textos desconocidos de Jerónimo de Carranza a propósito del XI Conde de Niebla y Mateo Vázquez (con unas notas sobre Hernando de Vega)", en El Duque de Medina Sidonia: mecenazgo y renovación estética, ed. José M. Rico y Pedro Ruiz Pérez, Huelva, Servicio de Publicaciones de la Universidad, 2015, pp. 119-142; “¿Topografía o topotesia en el entorno espiritual del Conde de Niebla?: sobre Soledades contemplativas y el Retrato de Pedro Espinosa (con dos documentos inéditos)", e-Spania. Revue interdisciplinaire d'études hispaniques médiévales et modernes, 23 (2016), accesible en http://e-spania.revues.org/25264; Vidas de arte en el humanismo hispalense; El asno de oro (Medina del Campo, 1543); $\mathrm{y}$ "El asno de oro»: un viaje de metamorfosis hacia Cervantes, Lope, Góngora y Quevedo.

95 En consonancia además con un palmario interés por personajes como "Escandarbeg, rey de Albania”, evocado en La Austríada, XXII, 121 (Juan Rufo, op. cit., p. 761). No obstante, resultó ser esta una figura elogiada con frecuencia en el Hércules animoso y sobre la que estuvo trabajando Mal Lara hasta su fallecimiento en 1571, en concreto en un proyecto ofrendado al Duque de Sessa. 
atalaya humanística, traigo seguidamente a colación varios versos significativos de La Austríada (XXIV, 95, 96 y 102) en los que Rufo se decantó por atender dicho temperamentum humanístico en virtud del canon culto y estilo sublime de la épica novelesca. Además, el Jurado de Córdoba se sirve en estos versos del conocido símil épico desde Homero, autor recordado por cierto en Apot. 215 por el hecho de haberse apropiado de las obras de una mujer ${ }^{96}$, y Virgilio hasta culminar en la épica imperial mencionada, con resonancias en el Hércules animoso y La Psyche de Mal Lara:

Ya deve acercarse el cumplimiento de aquella memorable profecía; ya se descubre el blanco del intento con que el divino intérprete dezía: “Tiempo vendrá en que el mundo de aposento a un pastor solo y a una monarquía, por una sola ley será guïada la tierra y de un govierno sojuzgada”.

Ya la ausencia del sol humedecía los prados, arboledas y montańas, y sus doradas clines esparzía sobre otras gentes bárbaras y extrañas; cuando en dulce conceto y harmonía, agradeciendo a Dios gracias tamañas, le cantaron: "Señor, a ti alabamos, a ti por señor confessamos.”.[...]

Como en la esgrima suele el buen maestro al discípulo ser más provechoso, moviendo contra él su braço diestro con ademán colérico y furioso: acométele a diestro y a siniestro, y es en ejecutar tan pïadoso, que el dócil moço dexa salvo y sano con más compás de pies y presta mano. ${ }^{97}$.

96 Juan Rufo, op. cit., p. 82.

97 Juan Rufo, op. cit., p. 850. 
De otro lado, en lo que hace a las claves paremiológicas armonizadas con la tradición clásica épico-novelesca, como se venía practicando en el entorno humanístico hispalense, resulta necesario poner de relieve la inserción por parte de Rufo de la modalidad épica en el género epigramático, o "epigramatario", de los Apotegmas, tan elogiados por insignes figuras como fray Basilio Ponce de León, en sus Discursos para todos los evangelios de la Cuaresma (1605), y que resultó ser deudo de fray Luis de León, en un contexto de humanismo cristiano y erasmismo postridentino desde Rufo, el propio fray Luis de León, el Brocense y Mal Lara con culminación, en fin, en Cervantes. Sea como fuere, el proceder estético de Rufo explica más allá de la obligada representación entre la realidad y la ficción de don Juan de Austria, la de Felipe II y otros personajes de la tradición histórico-literaria; así cabe mencionar las hijas del Cid (Apot. 359), Gonzalo Fernández de Córdoba, el Gran Capitán (Apot.I), don Antonio de Leyva, general de galeras (Apot. 289-290), el capitán don Diego de Escobar (Apot. 541) o el soldado Ruy González (Apot.538) ${ }^{98}$, que viene a recordar, por su similitud fónica en "Ruy", el nombre de Ruy Pérez de Viedma en Cervantes; de manera análoga, no están ausentes tampoco las alusiones y los apuntes a sus cargos, como consejero de guerra (Apot.428), sus atributos, por ejemplo Capitán como nombre de caballo (Apot.470), y hasta fórmulas, estilemas y expresiones del tipo "catedrático de valentía” (Apot.70). En cuanto a Felipe II en concreto, Rufo evoca al monarca sin necesidad de cronistas (Apot.353), en una escenificación ciertamente teatralizada de una anécdota (Apot. 549), con objeto de una comida (Apot.139), o en lo que hace a su protocolaria salutación al rey, con autorrepresentación de paso en el discurso literario (Apot. 601) ${ }^{99}$.

Pero además de la impronta de esta tradición épico-novelesca en la obra de Rufo, no hay que olvidar asimismo la amplia y granada tradición de novelas cortas, cuentos o facecias difundidos en la Sevilla humanística del momento, con la colaboración en esta línea de experimentación creativa, incluso hasta conjunta, de Mal Lara y el licenciado Tamariz, al calor de la tradición desde Apuleyo a Boccaccio revestida de visible sabor popular, que tendrá sus resonancias en Joan de Timoneda con obras como El

98 Juan Rufo, op. cit., pp. 131-132, 15-16, 108-109, 189 y 188.

99 Juan Rufo, op. cit., pp. 152, 167, 37, 129-130, 192-193, 58 y 209. 
buen aviso y portacuentos (1563) o El Patrañuelo (1567) ${ }^{100}$. A ello podemos añadir la pervivencia de la tradición clásica en las obras de Rufo ${ }^{101}$, como bien pudo comprobar Cervantes, en la línea conceptual del pensamiento filosófico y ejemplaridad de Séneca, a propósito de la conciencia del paso del tiempo y la brevedad de la vida, evocado por el Jurado de Córdoba en Apot. $158^{102}$. Con todo, sobresale a la vez, a modo de contraste, su marcado toque y concepto epigramático, graciosidad, agudeza y arte de ingenio, rasgos característicos igualmente en el entorno humanístico hispalense y ensalzados, andado el tiempo, por Baltasar Gracián en su Agudeza y arte de ingenio, con don Juan de Austria al fondo, por el hecho de que Rufo fue "jurado que juró de agudo", llegando a ser parangonado al poeta de Bílbilis, Góngora y hasta Marino ${ }^{103}$. En cualquier caso, baste recordar la pervivencia de Marcial, III, 43 ("Mentiris iuvenem") en Apot. 432 104 , con implicaciones en Cervantes, quien pudo familiarizarse también con su característica estructura triádica rematada por el acumen o esperable aguijón conclusivo en la que se integra escenificación y pregunta-respuesta, en virtud de la armonización de prosa y verso, y a partir de las modalidades dramática, poética y sentenciosa.

Sea como fuere, esta inclinación por la agudeza de fuste humorístico, revestida de apuleyanismo hispalense, podría explicar no solo la imitación de El asno de oro respecto al episodio de los odres como antesala de la historia del cautivo, sino también el cierre final, en calidad de acumen

100 Véanse de Juan de Timoneda: Buen aviso y portacuentos. El sobremesa y alivio de caminantes. Cuentos, ed. M. a Pilar Cuartero y Maxime Chevalier, Madrid, Espasa-Calpe, 1990;

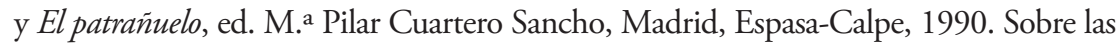
relaciones entre Tamariz y Mal Lara estoy preparando un estudio en fase avanzada.

101 Baste recordar como un representativo botón de muestra: Daniel López-Cañete Quiles, "El enigma de Rufo (y de Lesbia)", en "Pro tantis redditur». Homenaje a Juan Gil en Sevilla, coord. Rocío Carande y Daniel López-Cañete Quiles, Sevilla, Universidad, 2011, pp. 131-156.

102 Juan Rufo, op. cit., p. 63.

103 Véase Baltasar Gracián, Agudeza y arte de ingenio, ed. Ceferino Peralta, Jorge M. Ayala y José M. ${ }^{a}$ Andreu, Zaragoza, Larumbe Clásicos aragoneses, Prensas Universitarias de Zaragoza - Instituto de Estudios Altoaragoneses - Dpto. de Educación, Cultura y Deporte del Gobierno de Aragón, 2004, pp. 120, 130, 134-135, 142, 155, 185-186, 194, 224, 232, 281, 292, 305, 311, 313, 345, 361, 382, 399, 446, 485, 499, 501-503 y 627.

104 Juan Rufo, op. cit., p. 153. 
o aguijón narrativo, de dicha historia del cautivo, con apunte circular o en anillo al gigante de los cueros de vino, de sabor apuleyano, dado que, llegando la noche, don Quijote "se ofreció a hacer la guardia del castillo, porque de algún gigante o otro malandante follón no fuesen acometidos [...]"105. De hecho, no falta cierto toque de humor o graciosidad, tan del gusto de los humanistas apuleyanos de la Sevilla áurea, por parte de los personajes de la venta ante la ocurrencia de don Quijote como realce de la parodia compleja cervantina, en términos de Edward C. Riley ${ }^{106}$ : “[...] dieron al oidor cuenta del humor estraño de don Quijote, de que no poco gusto recibió." ${ }^{107}$. En definitiva, resulta claro que tanto Rufo como Cervantes se decantaron por claves temático-conceptuales con las que se propusieron armonizar el canon sublime de la épica novelesca y el humilde y gracioso de la cultura popular y paremiológica, asentada en la ciudad de la Giganta de Sevilla, a medio camino entre una nueva Roma, una Jerusalén rediviva pero también, al tiempo, una Babilonia renaciente como "espacioso campo" para otra picaresca cervantina.

\section{Moros, CRISTIANOS Y "COSARIOS" EN EL LABORATORIO EXPERIMENTAL CERVANTINO}

\section{1. Macroestructura narrativa}

A la vista de lo expuesto en las páginas precedentes, Cervantes encontró en el imaginario estético de Rufo un método narrativo, de calado épico-novelesco, implementado en historias de moros y cristianos en $\mathrm{La}$ Austriada, con trama amorosa de por medio protagonizada por Huzen y Zara, y con presencia de "cosarios" o piratas; por tanto viene a ser, en sín-

105 Miguel de Cervantes, op. cit., p. 547.

106 Categoría conceptual que propone en sus conocidos estudios monográficos: Cervantes's Theory of the Novel, Oxford, Oxford Clarendon Press, 1962; Introducción al «Quijote», trad. Enrique Torner Montoya, Barcelona, Crítica, 2000; y La rara invención. Estudios sobre Cervantes y su posteridad literaria, trad. M. ${ }^{a}$ Carmen Llerena, Barcelona, Crítica, 2001.

107 Miguel de Cervantes, op. cit., p. 547. 
tesis, una prefiguración in nuce de la historia del cautivo ${ }^{108}$, desarrollada ampliamente por el autor del Quijote y con ensayos previos en su laboratorio experimental, desde el relato de Timbrio en La Galatea, también un menage à trois entre él mismo, Silerio-Astor y Nísida ${ }^{109}$, como sucede con Huzen, Zara y Diego Alguacil, a La española inglesa. Para este laboratorio experimental hay que tener en cuenta además, como he venido apuntando, el contexto previo de Quijote I, 37, a propósito de la venta y la lectura de El curioso impertinente, con cueros de vino de sabor apuleyano, cosas de encantamento y remedo de épica novelesca mediante destreza con el supuesto gigante como parodia compleja, la "transformación" de la princesa Micomicona (Dorotea), la historia de Fernando, y hasta el discurso previo de las armas y las letras (I, 37-38) merecedor, como se recordará, del aplauso del cura. De hecho, sobresalen apuntes a la figura del soldado letrado, así como el mensaje irenista de filiación erasmiana (“paz, el mayor bien que los hombres pueden desear en esta vida”) ${ }^{110}$. Se trata, en cualquier caso, de una estructura circular o anular epigramática (Ringkomposition) planteada por Cervantes, dado que el final del discurso de la vida del cautivo, es decir el cierre de I, 41, conduce de nuevo al lector al contexto espacio-temporal de la venta, incluyendo los circunstan-

108 Sobre esta convivencia de moros y cristianos en el pensamiento estético de Cervantes: Ellen M. Anderson, "Playing at Moslem and Christian: The Construction of Gender and the Representation of Faith in Cervantes' Captivity Plays", Cervantes. Bulletin of the Cervantes Society of America, 13.2 (1993), pp. 37-60; Robert S. Stone, "Moorish Quixote: Reframing the Novel", Cervantes. Bulletin of the Cervantes Society of America, 33.1 (2013), pp. 81-112; y Nisrin Ibn Larbi, La dualidad cervantina: historia, literatura y moriscos en el Siglo de Oro, Tesis doctoral dirigida por Miguel Ángel García, Granada, Universidad, 2017.

109 Para otros pormenores de este triángulo amoroso, con música de fondo: Francisco J. Escobar, "Resuene el cuento de Silerio: Psalle et sile o intersecciones dialogísticas en La Galatea (con tres variaciones y rondó final)", e-Spania. Revue interdisciplinaire d'études hispaniques médiévales et modernes, 29, 2018, pp. 1-43.

110 Miguel de Cervantes, op. cit., p. 485. Sobre la estela irenista de Erasmo, con el traductor de El asno de oro de por medio: Francisco J. Escobar, "Diego López de Cortegana y Erasmo: la traducción de la Querela Pacis (Sevilla, Jacobo Cromberger, 1520)", en La «metamorfosis» de un inquisidor: el humanista Diego López de Cortegana (1455-1524), eds. Francisco J. Escobar, Samuel Díez y Luis Rivero, Sevilla - Huelva, Universidad de Sevilla - Universidad de Huelva - Ayuntamiento de Cortegana, 2013, pp. 133-163. 
tes que escuchan absortos y embebecidos al protagonista. Es más, como broche circular de la macroestructura narrativa en la que Cervantes ha integrado a su vez la historia del cautivo, don Quijote asemeja la venta al castillo, al tiempo que vuelve a recordar el binomio armas y letras ${ }^{111}$; o sea, como en su discurso, previo al cuento del capitán cautivo.

Cervantes interviene, por tanto, no solo como maestro concertante de su macroestructura genérica y los hilos narrativos puestos en escena, sino también como autor caché, con un apunte metaliterario de paso a la brevedad expositiva, conforme a la breuitas et concinnitas, hasta el punto de que el cautivo, alter ego del escritor, somete a tela de juicio crítico su historia $^{112}$. No es de extrañar por ello que en I, 42 ("Que trata de lo que más sucedió en la venta y de otras muchas cosas dignas de saberse") el lector halle un examen valorativo de la historia del cautivo por parte de don Fernando, en tanto que este, Cardenio y los demás personajes se habían ofrecido al capitán cautivo y a Zoraida para prestarles su ayuda, incluso en lo que hacía al bautismo de la joven, aunque el capitán cautivo finalmente no acabe aceptando dicho apoyo y respaldo. Se produce, sea como fuere, la paulatina modulación transitoria a otros sucesos, en concreto la llegada del oidor y la presencia todavía en escena del cautivo ("En esto llegaba la noche, y al cerrar della llegó a la venta un coche [...]”). De hecho, el oidor se presenta acompańado de una doncella cuya belleza llega a igualar a la de Dorotea, Luscinda y Zoraida ${ }^{113}$, mientras que el capitán cautivo, al contemplar el rostro y presencia del oidor, o sea Juan Pérez de Viedma, natural de "un lugar de las montañas de León", presiente que se trata de su hermano ${ }^{114}$; es decir, el joven que había seguido el camino de las letras, uno de los tres oficios propuestos por el padre de los tres hermanos, a modo de consejo, como arquetipo cuentístico de sabor folclórico ${ }^{115}$. Sea

111 Miguel de Cervantes, op. cit., p. 541.

112 Cf.: "No tengo más, señores, que deciros de mi historia; la cual si es agradable y peregrina júzguenlo vuestros buenos entendimientos, que de mí sé decir que quisiera habérosla contado más brevemente puesto que el temor de enfadaros más de cuatro circunstancias me ha quitado de la lengua." (Cervantes, op. cit., p. 539).

113 Miguel de Cervantes, op. cit., pp. 541-542.

114 Miguel de Cervantes, op. cit., pp. 542-544.

115 Miguel de Cervantes, op. cit., pp. 493-495. Para otros pormenores: Angela Irwin y Alfred Rodríguez, “"El capitán cautivo» de Cervantes: ¿Barroca hibridización de historia y folklore?”, Anales cervantinos, 32 (1994), pp. 259-264. 
como fuere, Juan Pérez de Viedma, por su parte, había viajado a Indias, residiendo en la Audiencia de México, en tanto que la doncella hermosa resultaba ser su hija, nacida, según se refiere en la trama narrativa, de un parto complicado en el que falleció su madre ${ }^{116}$; o sea, una vez más, otro motivo procedente del folclore. El cura, a su vez, decide realizar una síntesis o vida abreviada del capitán cautivo, Ruy Pérez de Viedma ${ }^{117}$, ante la escucha de su hermano "oidor", con una modulación hacia las patrañas de las viejas, es decir al igual que en El asno de oro, los Disticha Catonis, transmitidos en pliegos sueltos (Castigos y ejemplos de Catón), y el subtema o motivo de la libertad perdida para el capitán cautivo en Lepanto, alter ego de Cervantes. El cura, en fin, le recuerda al oidor que a su hermano Ruy, el capitán cautivo, "fuele la fortuna contraria, pues donde la pudiera esperar y tener buena, allí la perdió, con perder la libertad en la felicísima jornada donde tantos la cobraron, que fue en la batalla de Lepanto" ${ }^{118}$.

Por último, el cura llega al "final de su cuento" o "conseja", en un marco espacio-temporal (cronotopo) en el que el oidor acabará reconociendo a su hermano Ruy, el capitán cautivo ${ }^{119}$, en una anagnórisis característica de la novela griega, con la que venía a presentar también analogías, a efectos de caracterización genérica, El asno de oro, tan arraigado en la Sevilla del Siglo de Oro. Asimismo, el oidor viene a sintetizar los consejos de su padre, con los que comenzaba la macroestructura narrativa cervantina, y los oficios de sus hermanos, de los que el "menor [...] está en el Pirú" ${ }^{120}$. La trama concluye, en suma, con el efusivo pero cálido abrazo de amistad entre los dos hermanos presentes en la situación narrativa y la manifestación de sentimientos, afectos y emociones imposibles de llevarse a la escritura,

116 Miguel de Cervantes, op. cit., p. 543.

117 Esto es, desde una perspectiva complementaria a la autobiografía soldadesca; véase: Adrián J. Sáez, "Vida del capitán Ruy Pérez de Viedma: la autobiografía soldadesca en Don Quijote (1.39)", Cervantes. Bulletin of the Cervantes Society of America, 36.1 (2016), pp. 85-104.

118 Miguel de Cervantes, op. cit., p. 544.

119 Miguel de Cervantes, op. cit., pp. 545-546.

120 Miguel de Cervantes, op. cit., p. 545. En lo que hace a la relación entre los tres hermanos y sus implicaciones literarias en la historia cervantina: Clark Colahan, "Comedia del valor de las letras y las armas: nueva luz sobre la historia del capitán cautivo y sus hermanos (DQ 1, 37-45)", Anales cervantinos, 47 (2015), pp. 171-182. 
en un apunte cervantino a la cortedad del decir, a modo de exhaustio ${ }^{121}$. Por lo demás, don Quijote se viene a mostrar como un atento espectador del caso atribuyéndolo "a quimeras de la andante caballería" 122 , mientras se acuerda por parte de los circunstantes que, puesto que el oidor partiría desde allí a la Nueva España, el capitán cautivo y Zoraida se encaminen con su hermano a Sevilla, enclave, una vez más, de proyección humanística épico-novelesca connotado tanto para Cervantes como para Rufo, con concierto de bodas ${ }^{123}$, seguramente en una réplica estético-conceptual a la historia de Ozmín y Daraja en Guzmán de Alfarache del también hispalense Mateo Alemán. Finaliza el capítulo I, 52 con la voz de un mozo que canta y encanta con "Marinero soy de amor" a los presentes, entre ellos Dorotea, para dar paso a otras historias, como la de dońa Clara y don Luis, y "estraños acaecimientos en la venta" en I, 53 ("Dónde se cuenta la agradable historia del mozo de mulas, con otros estraños acaecimientos en la venta sucedidos') ${ }^{124}$.

6. 2. Cervantes y Rufo escritores con espada (al calor de don Juan de Austria y Lepanto)

Según he venido apuntando, resulta visible cierta correspondencia analógica de realidad y ficción entre la experiencia de Cervantes y la de Rufo como soldados letrados en Lepanto ${ }^{125}$, más allá de géneros literarios tradicionales y canónicos como la épica al uso o la novela griega. La Austríada en sí venía a proporcionar a Cervantes un rico caladero de temas, subtemas y motivos épico-novelescos desde las guerras en las Alpujarras,

121 Cf.: "Las palabras que entrambos hermanos se dijeron, los sentimientos que mostraron, apenas creo que pueden pensarse, cuanto más escribirse. Allí en breves razones se dieron cuenta de sus sucesos, allí mostraron puesta en su punto la buena amistad de los dos hermanos [...]" (Miguel de Cervantes, op. cit., p. 546).

122 Miguel de Cervantes, op. cit., pp. 546-547.

123 Miguel de Cervantes, op. cit., p. 547; cf. también el relato inicial del capitán cautivo sobre su destino y el de sus dos hermanos a raíz de lo prometido a su padre: "Prometímoselo, y, abrazándonos y echándonos su bendición, el uno tomó el viaje de Salamanca, el otro de Sevilla, y yo el de Alicante [...]" (Cervantes, op. cit., p. 495).

124 Miguel de Cervantes, op. cit., pp. 547-548.

125 Para otras consideraciones afines y complementarias: José López de Toro, Los poetas de Lepanto, Madrid, CSIC - Instituto Histórico de Marina, 1950. 
a modo de arranque de la obra, con etopeya de don Juan de Austria, en la que se identifican apuntes a su "nacimiento y crianza deste príncipe", hasta la cruenta guerra contra Abenhumeya y "los del Albayzín”, entre otros episodios presididos por el maridaje de historia verdadera y ficta. Tanto es así que, como es sabido, Rufo llegó a acompañar a don Juan de Austria no sólo en la contienda de Lepanto (1571) sino también en esta campaña de Granada contra los moriscos sublevados (1568), que bien interesó a los hombres de letras hispalenses, como recuerda Mal Lara en el Hércules animoso, obra por otra parte en la que participaron humanistas de la talla de Mosquera de Figueroa, Herrera o Carranza.

Sea como fuere, más allá de la insustituible vivencia y experiencia vital del propio Rufo, cabe poner de relieve la notoriedad de la Historia de las guerras de Granada de Diego Hurtado de Mendoza en los dieciocho cantos iniciales de La Austriada, con elementos temáticos afines y resonancias intertextuales en Apot. 287, a modo de ciclo revestido de pátina épiconovelesca y con factura paremiológica dedicado a D. Juan de Austria en $1,54,55,91,287,548,550,572$ ó $630^{126}$. Estamos, además, ante una manifiesta influencia de la tradición literaria previa desde los Apotegmas de Plutarco, con traducción al cuidado de Diego Gracián, a la Floresta española de apotegmas y sentencias, sabia y graciosamente dichas, de algunos españoles de Melchor de Santa Cruz, dedicada a Juan de Austria ${ }^{127}$, ecos todos ellos que dejaron su calado y vigencia en el pensamiento estéticoconceptual de Rufo hasta tener su proyección ulterior en Cervantes, por ejemplo en los conocidos apotegmas de Tomás Rodaja en El licenciado Vidriera.

Ahora bien, sin duda alguna, viene a destacar en un lugar preeminente la presencia de don Juan de Austria en el discurso de la vida del cautivo cervantino, hasta con cronología interna ${ }^{128}$. De hecho, su relato ofrece

126 Juan Rufo, op. cit., pp. 107-108, 15-16, 30, 30-31, 44-45, 107-108, 192, 193, 200 y 219.

127 Puede leerse en la edición al cuidado de M. ${ }^{a}$ Pilar Cuartero y Maxime Chevalier: Melchor de Santa Cruz, Floresta española, Barcelona, Crítica, 1997.

128 Veamos varios ejemplos: "Volvimos a Constantinopla, y el ańo siguiente, que fue el de setenta y tres, se supo en ella cómo el señor don Juan había ganado a Túnez y quitado aquel reino a los turcos y puesto en posesión dél a Muley Hamet, cortando las esperanzas que de volver a reinar en él tenía Muley Hamida, el moro más cruel y más valiente que tuvo el mundo [...].; y el año siguiente de setenta y cuatro acome- 
una visible tonalidad épico-novelesca con derivaciones genéricas hacia la novela griega en la que tiene cabida la amplificatio comentada conforme a la "experiencia" del episodio de la Goleta y el fuerte ordenado por don Juan de Austria ${ }^{129}$, frente a "los que hablan de lejos y con poca experiencia de casos semejantes"130. Se trata, claro está, de una épica novelesca sustentada sobre la experiencia vivida, y vívida, reconocible en el discurso de la vida del cautivo, que presenta a su vez notable sabor épico tomando como referente a don Juan de Austria, elevado a la categoría de héroe; por ejemplo cuando los cristianos consiguen domeñar a los moros ${ }^{131} y$ al hilo del asalto de los "cosarios" o piratas franceses de La Rochela a los cristianos con piezas de artillería, "arcabuces y cuerdas encendidas"132. De modo análogo, en este episodio, con puntos de encuentro respecto al relato biográfico y épico-novelesco de Timbrio en La Galatea, como se ha apuntado, el cautivo teme por la castidad de Zoraida, en correspondencia con la de Nísida, no por sus joyas materiales. Con todo, estos piratas solo desean satisfacer sus ansias de codicia y finalmente no atentarán contra la integridad sexual de la joven musulmana ${ }^{133}$. En síntesis, de manera simi-

tió a la Goleta y al fuerte que junto a Túnez había dejado medio levantado el señor don Juan" (Miguel de Cervantes, op. cit., pp. 499-500).

129 Cf.: "-Perdiose, en fin, la Goleta, perdiose el fuerte [...]. Perdiose primero la Goleta, tenida hasta entonces por inexpugnable, y no se perdió por culpa de sus defensores [...], sino porque la experiencia mostró la facilidad con que se podían levantar trincheas en aquella desierta arena. [...] Perdiose también el fuerte, pero fuéronle ganando los turcos palmo a palmo, porque los soldados que lo defendían pelearon tan valerosa y fuertemente, que pasaron de veinte y cinco mil enemigos los que mataron en veinte y dos asaltos generales que les dieron" (Cervantes, op. cit., pp. 500-501).

130 Miguel de Cervantes, op. cit., p. 501.

131 Cf:: "Ya a este tiempo habían entrado dentro casi todos los cristianos. Los moros, que eran de poco ánimo, viendo hablar de aquella manera a su arráez, quedáronse espantados, y sin ninguno de todos ellos echar mano a las armas, que pocas o casi ningunas tenían, se dejaron, sin hablar alguna palabra, maniatar de los cristianos, los cuales con mucha presteza lo hicieron, amenazando a los moros que si alzaban por alguna vía o manera la voz, que luego al punto los pasarían todos a cuchillo" (Miguel de Cervantes, op. cit., p. 525).

132 Miguel de Cervantes, op. cit., pp. 533-534.

133 Cf.: "Pero no me daba a mí tanta pesadumbre la que a Zoraida daban como me la daba el temor que tenía de que habían de pasar del quitar de las riquísimas y pre- 
lar a Rufo, Cervantes se vale en tales episodios de fórmulas narrativas de aliento épico-novelesco, conjugadas a su vez con la etopeya y la caracterización humanizada de los protagonistas, entre sentimientos y emociones complejas tales como la crueldad, la ira y el odio ${ }^{134}$.

6.3 Soldadesca: del canon sublime de la épica ficcionalizada al humilde de la cultura popular (con sonetos al fondo)

Además de las deudas referidas de Cervantes respecto a Rufo, quiero subrayar el interés de estos dos escritores por la intrahistoria en términos unamunianos de la soldadesca, en una propuesta renovada respecto a la poética a noticia vs. a fantasía del "artificioso" Bartolomé de Torres Naharro en la Propalladia, como se llega a manifestar en La Galatea. En concreto, Cervantes debió ser bien sensible al universo de los soldados anónimos, o casi anónimos, recreados por Rufo en la ficción de La Austríada y sobre todo en Apotegmas; así a propósito del soldado poeta (214), la amistad entre milicianos (553), la historia de vida de estos protagonistas innominados $(355,538)$, el caso de un combatiente pobre y enamorado de una dama rica (64), el amante de genízara (212), otro seductor de una nińa de once años (295) y la anécdota de una jovenzuela entre soldados (317), el caso del huérfano vergonzoso (382), el avariento $(104,106)$ y otros estereotipos de sabor folclórico tales como el del viejo y buboso en Madrid (475), el mareado en barco (630), con elogio del uniforme (637), así como el apunte al paje del soldado que apenas se alimentaba (663), la facecia o chascarrillo de hacerse soldado por huir de la esposa (671), la vida de un soldado no mencionado en La Austríada (476), el mundo de la soldadesca en Nápoles (475), o, en fin, los juegos de ingenio y agudeza a propósito del soldado - sólo el dado (198) ${ }^{135}$.

ciosísimas joyas al quitar de la joya que más valía y ella más estimaba” (Miguel de Cervantes, op. cit., p. 534).

134 Cf.: "Y no quiero dejar de decir lo que sucedió en la presa de La Presa. Era tan cruel el hijo de Barbarroja y trataba tan mal a sus cautivos [...]; tal era, como he dicho, la crueldad con que los trataba y el odio que ellos le tenían" (Miguel de Cervantes, $o p$. cit., p. 499).

135 Juan Rufo, op. cit., pp. 82, 193-194, 150, 188, 34, 81, 110, 119, 138, 48, 49, 168, 219, 222, 230, 232, 169, 168 y 76. 
Se trata, en efecto, de estilemas de la soldadesca bien humanizados y sin "artificio" alguno que vienen a tener su paralelo en Quijote I, 39 ("Donde el cautivo cuenta su vida y sucesos"): "En un lugar de las montañas de León tuvo principio mi linaje", "padre fama de rico", "soldado los ańos de su joventud", "es escuela la soldadesca”... ${ }^{136}$; en suma, la vida como género, recurso literario y hasta elevado a la categoría de método para otra épica novelesca, más humanizada conforme al saber y experiencia popular, además de los experimentos de calado picaresco ${ }^{137}$, que Cervantes encontró igualmente en El asno de oro (cf. infra), de tradición hispalense gracias ya a la traducción al castellano en 1513 por el arcediano Diego López de Cortegana en el taller de su amigo colaborador Jacobo Cromberger; o lo que es lo mismo, otra épica cervantina, novelesca y humanizada, alternativa a los experimentos y formalizaciones de aclamados ingenios áureos de la época como Lope de Vega, quien se inspiró por cierto en los Apotegmas de Rufo en las Rimas de Tomé Burguillos ${ }^{138}$.

En otras palabras, habida cuenta de este manifiesto interés tanto por parte de Rufo como de Cervantes por el retrato del soldado, entre la etopeya y la prosopografía, incluyendo la figura del escritor miliciano, no es de extrañar la presencia en el Prólogo de las Novelas ejemplares de la construcción épico-novelesca de su autor como escritor soldado, es decir, poeta con espada frente al poeta a secas, como en Apot. 442 y 214, con paradigma ejemplar en Francisco de Aldana (Apot. 183, 297) ${ }^{139}$; lo hace, de hecho, el autor del Quijote a partir de su inserción en el discurso estético-narrativo mediante la autorrepresentación, la autorreferencialidad y hasta con marca autorial-perfil de autor. Además, en consonancia con esta técnica o estrategia discursiva entre la realidad y la ficción, deben situarse al unísono los paralelos o lugares comunes respecto al discurso de la vida del cautivo cervantino, quien llega a recordar en el catálogo épico a un soldado poeta andaluz recreado en la ficción, como contrapunto a los

136 Juan Rufo, op. cit., p. 493.

137 Sin llegar a redactar nunca Cervantes, como es sabido, una novela canónica adscrita a este género.

138 Véase el análisis de Ignacio Arellano, “Un soneto de Lope («Duerme el sol de Belisa en noche escura»), supuestamente envilecido, y su fuente", Revista de Filología Espanola, 91.2 (2011), pp. 337-342.

139 Juan Rufo, op. cit., pp. 156-157, 82, 71 y 111. 
reales; es decir, un tal (quidam) Pedro de Aguilar, adalid por otra parte de la fortitudo et sapientia, con Cervantes como autor caché ${ }^{140}$.

Pues bien, en dicho contexto narrativo, don Fernando, hermano de don Pedro de Aguilar, decide interrumpir al cautivo con la intención de preguntarle por la fortuna de este último, en tanto que le viene a responder a tal cuestión en una visible humanización del soldado poeta, con apunte de paso al qui pro quo, de raigambre escénico de fondo ${ }^{141}$. Por lo demás, el caballero deja ver que se sabe de memoria, y hasta con recitación performativa de coro, los dos sonetos de su hermano; de hecho, en I, 49 ("Donde se prosigue la historia del cautivo") don Fernando comienza a recitar el soneto a la Goleta ("Almas dichosas que del mortal velo") y el Fuerte ("De entre esta tierra estéril, derribada") ${ }^{142}$. Se trata, en cualquier caso, de un contexto ficticio que tiene su correspondencia paralelística en los sonetos preliminares de La Austriada, entre los cuales se halla, claro está, el de Cervantes, “ Oh venturosa, levantada pluma”, con notas de historia verdadera y fingida a propósito de "calle de hoy más el escriptor de Numa" (v. 5); "y no menos dichoso todo el suelo / que de tanto bien goza en esta historia" (vv. 10-11) ${ }^{143}$. No obstante, dicha tradición del soneto epigramático, con la que entronca aquí Cervantes, acompañado también del "Cantaste, Rufo, tan heroicamente" de Góngora heroico ${ }^{144}$, se relacio-

140 Cf.: “[...] natural no sé de qué lugar del Andalucía, el cual había sido alférez en el fuerte, soldado de mucha cuenta y de raro entendimiento; especialmente tenía particular gracia en lo que llaman poesía."; "[...] y antes que nos partiésemos de aquel puerto hizo este caballero dos sonetos a manera de epitafios, el uno a la Goleta y el otro al fuerte. Y en verdad que los tengo de decir, porque los sé de memoria y creo que antes causarán gusto que pesadumbre" (Miguel de Cervantes, op. cit., p. 502).

141 Cf.: "-Lo que sé es — respondió el cautivo- que al cabo de dos años que estuvo en Constantinopla, se huyó en traje de arnaute ['albanés'] con un griego espía, y no sé si vino en libertad, puesto que creo que sí, porque de allí a un año vi yo al griego en Constantinopla y no le pude preguntar el suceso de aquel viaje.

-Bueno fue - respondió el caballero-, porque ese don Pedro es mi hermano y está ahora en nuestro lugar, bueno y rico, casado y con tres hijos.

- Gracias sean dadas a Dios — dijo el cautivo_ por tantas mercedes como le hizo, porque no hay en la tierra, conforme mi parecer, contento que se iguale a alcanzar la libertad perdida." (Miguel de Cervantes, op. cit., p. 503).

142 Miguel de Cervantes, op. cit., pp. 502-503.

143 Juan Rufo, op. cit., p. 896.

144 Juan Rufo, op. cit., p. 896 . O lo que es lo mismo, Góngora con su propuesta épica 
na con la notable práctica de sonetos epigramáticos del aludido humanismo hispalense en los places of knowledge o lugares de saber en torno a don Juan de Austria y la Descripción de la Galera real de Juan de Mal Lara. Tanto es así que Rufo fue un excelente conocedor (y testigo de primera mano) de esta tradición culta de sonetos epigramáticos o epigramatarios, explicados por Herrera en sus Anotaciones a Garcilaso de la Vega, cuando se refiere a ella en Apot. 54, a propósito de un soneto de escaso valor literario en el estanterol ${ }^{145}$ de la Real que no le gustó, al parecer, a don Juan de Austria ${ }^{146}$.

A buen seguro, este diálogo de sonetos epigramáticos entre la realidad y la ficción, con Rufo y Cervantes como escritores protagonistas, deben ser contextualizados, una vez más, en esta fértil tradición humanística hispalense que viene a explicar el desarrollo y evolución del canon culto en la década de los ochenta del siglo XVI, según se recuerda en El Canto de Caliope. No obstante, desde esta atalaya y cumbre estética se incluyen además relaciones, referentes historiográficos y modalidades literarias experimentales consonantes con La Austríada; es el caso de uno de los modelos seńeros para el autor de la historia del cautivo, es decir, Herrera y su mencionada Relación de la guerra de Cipre, y suceso de la batalla Naval de Lepanto (1572), con coda final en la canción dedicada a don Juan de Austria, en concreto en una de sus variantes redaccionales.

Por tanto, el análisis comparativo e intertextual planteado hasta el momento, en definitiva, pone de relieve, como en el caso de Cervantes, las conexiones de Rufo con el entorno humanístico hispalense y su tradición de sonetos epigramáticos en torno a don Juan de Austria y la Galera

tan singular respecto a las variadas formalizaciones genéricas de Lope de Vega y esta épica novelesca humanizada de Cervantes; véase: Mercedes Blanco, Góngora heroico: las "Soledades» y la tradición épica, Madrid, Centro de Estudios Europa Hispánica, 2012. Por otra parte, a estos versos preliminares de La Austríada cabe añadir otros de autores cercanos al entorno sociocultural de Cervantes; así Lupercio Leonardo de Argensola y sus estancias "Después que de claríssimos varones", con apuntes a Virgilio, Lucano y Séneca mediante translatio studii (Juan Rufo, op. cit., p. 894), es decir, modelos tanto de Rufo como del autor de la historia del cautivo en esta paulatina forja y conformación del género épico-novelesco en la Edad de Oro.

145 Término, por cierto, mencionado en la historia del cautivo: "[...] capitán, que estaba sobre el estanterol gritando que bogasen apriesa [...].” (Miguel de Cervantes, op. cit., p. 499). 146 Juan Rufo, op. cit., p. 30. 
real, más allá de la mera presencia de dicha ciudad en su obra ${ }^{147}$ a modo de topotesia ${ }^{148}$, que incluye su propia autorrepresentación en la capital andaluza (Apot. 527) al calor de mecenas y nobles como el marqués de Tarifa (692), y hasta el caballo Truhán (506) ${ }^{149}$, tan vinculado a este elenco erudito que hunde sus raíces en la Academia de Mal Lara, en la que estaban integrados, claro está, el propio Herrera, Mosquera de Figueroa y Carranza.

\section{VIDA COMO OBRA DE ARTE Y TRADICIÓN NARRATIVA MORISCA (CON CARTAS Y REQUIEBROS DE AMOR)}

Como se ha mencionado en apartados precedentes, la experiencia de la soldadesca en Rufo, como también en Cervantes, deja ver el concepto de vida como obra de arte, reconocible en estilemas o fórmulas tales como el "discurso de mi vida", el "retablo de la vida" o "teatro de figuras" (theatrum mundi), según se comprueba en Apot. 240 a propósito de "Enseña retablo" o en 444 en lo que hace al "tablado de comedias"150. De hecho, no resulta difícil evocar a este respecto evidentes paralelos textuales cervantinos tales como el Retablo de las maravillas y el retablo de Maese Pedro (Quijote, I, 22), uno de los galeotes liberado por don Quijote, o la mención de un "retablo" en El coloquio de los perros. Esto es, Rufo se sirve de elementos heterogéneos y plurales que vienen a representar su vida en las fronteras entre la realidad y la ficción, así lo deja ver la carta a su hijo, el pintor Luis Rufo en Apot. 653 ${ }^{151}$, con puntos de encuentro respecto al discurso o cuento de la vida del cautivo. No obstante, en este relato sobresale la irrupción del cautivo en la escena acompañado de Lela Zoraida, con belleza idealizada y conversión espiritual o metamorfosis mariana incluida, o lo que es lo mismo, un contexto bien cervantino en los baños de Argel, como refiere el cautivo, con recuerdo a un "tal Saavedra”.

147 En La Austriada, por ejemplo en VI, 113 (Juan Rufo, op. cit., p. 271).

148 En términos herrerianos en sus escolios circunscritos a la estética de Garcilaso de la Vega.

149 Juan Rufo, op. cit., pp. 184, 238 y 177.

150 Juan Rufo, op. cit., pp. 90-91 y 157.

151 Juan Rufo, op. cit., pp. 226-227. 
Seguidamente Cervantes viene a integrar la sugerente historia amorosa en el discurso de la vida del cautivo, en la que cobran protagonismo los amos, en confluencia con la marginalidad picaresca de sabor popular, el gnorisma ('señal') de la épica clásica, con la novela griega al fondo, e incluso "la verdad del caso", como venía a exponer Rufo en los preliminares de La Austríada, en la historia del cautivo, o sea Ruy Pérez de Viedma, con temas tan cervantinos como la libertad ${ }^{152}$.

Por lo demás, el cautivo había conseguido una esperanzadora dádiva y galardón por parte de Zoraida, con acentuada presencia de Agi Morato al fondo ${ }^{153}$, padre de Zoraida pero también personaje de sesgo histórico recreado igualmente por Cervantes en Los baños de Argel. En cualquier caso, destaca, en fin, otra perspectiva narrativa del cautiverio planteada por el autor del Quijote, ahora desde el prisma femenino, gracias a Zoraida Lela Marién, en una consabida polionomasia cervantina como evolución

152 Cf.: “[...] miré la ventana y vi que por ella salía una muy blanca mano [...]. Con esto entendimos o imaginamos [los presos] que alguna mujer que en aquella casa vivía nos debía de haber hecho aquel beneficio. [...] Esta señal nos confirmó en que alguna cristiana debía de estar cautiva en aquella casa [...]; pero la blancura de la mano y las ajorcas que en ella vimos nos deshizo este pensamiento, de ser cristiana renegada, a quien de ordinario suelen tomar por legítimas mujeres sus mesmos amos [...]. Y aunque en este tiempo procuramos con toda solicitud saber quién en aquella casa vivía y si había en ella alguna cristiana renegada, jamás hubo quien nos dijese otra cosa sino que allí vivía un moro principal y rico, llamado Agi Morato, alcaide que había sido de la Pata, que es oficio entre ellos de mucha calidad" (Miguel de Cervantes, op. cit., pp. 508-509).

153 En concreto: "[...] cuarenta escudos de oro españoles y un papel escrito en arábigo, $\mathrm{y}$ al cabo de lo escrito hecha una grande cruz [...]; y como ninguno de nosotros no entendía el arábigo, era grande el deseo que teníamos de entender lo que el papel contenía, y mayor la dificultad de buscar quien lo leyese. En fin, yo me determiné de fiarme de un renegado, natural de Murcia, que se había dado por grande amigo mío [...]. Pues uno de los renegados que he dicho era este mi amigo [...]. Supe que sabía muy bien arábigo, y no solamente hablarlo, sino escribirlo [...]. Preguntele si lo entendía; díjome que muy bien, y que si quería que me lo declarase palabra por palabra, que le diese tinta y pluma, porque mejor lo hiciese. Dímosle luego lo que pedía, y él poco a poco lo fue traduciendo, y en acabando dijo: «Todo lo que va aquí en romance, sin faltar letra, es lo que contiene este papel morisco, y hase de advertir que adonde dice Lela Marién quiere decir Nuestra Señora la Virgen María». Leímos el papel, y decía así: «Cuando yo era niña, tenía mi padre una esclava [...]»” (Miguel de Cervantes, op. cit., pp. 509-511). 
del personaje, quien acabará solicitando matrimonio y nupcias al cautivo ${ }^{154}$. Tanto es así que, por mediación de un renegado, el cautivo viene a responder al mensaje comprendido en el "billete de la mora"155, entre la escritura y la memoria ${ }^{156}$, a modo de carta ${ }^{157}$, mientras que prosigue el discurso de la vida del cautivo a la espera del "aviso segundo" de Zoraida ${ }^{158}$, quien le acaba proporcionando indicaciones al tiempo que le adelanta su deseo de que se comprometa en calidad de esposo, como también lo anhela un personaje apuleyano de El asno de oro, bien arraigado en la tradición humanística hispalense, como veremos más abajo, es decir, Psique.

Sea como fuere, más allá del claro entronque con la tradición epistolar desde las Heroidas de Ovidio hasta la prosa de ficción sentimental del siglo XV, contrahecha por cierto en la consabida carta de don Quijote a Dulcinea, estamos ante visibles loci communes en la trama amorosa incardinados en la amplia y granada tradición de narraciones moriscas en consonancia con Cervantes y su morisco Ricote en el Quijote, atribuido en la

154 Cf.: "Muchos cristianos he visto por esta ventana, y ninguno me ha parecido caballero sino tú [...]. Yo escribi esto, mira a quién lo das a leer; no te fies de ningún moro, porque son todos marfuces ['traidores, falsos']; [...] y si no tienes quien te escriba arábigo, dimelo por señas, que Lela Marién hará que te entienda; [...] Ella y Alá te guarden, y esa cruz que yo beso muchas veces que asi me lo mandó la cautiva" (Miguel de Cervantes, op. cit., p. 511).

155 Miguel de Cervantes, op. cit., p. 512.

156 Cf.: "[...] luego al momento el renegado escribió las razones que yo le fui notando, que puntualmente fueron las que diré, porque de todos los puntos sustanciales que en este suceso me acontecieron ninguno se me ha ido de la memoria, ni aun se me irá en tanto que tuviere vida. En efeto, lo que a la mora se le respondió fue esto: El verdadero Alá te guarde, señora mía, y aquella bendita Marién, que es la verdadera madre de Dios y es la que te ha puesto en corazón que te vayas a tierra de cristianos [...]." (Miguel de Cervantes, op. cit., pp. 512-513).

157 Cf.: "No dejes de escribirme y avisarme lo que pensares hacer, que yo te responderé siempre, que el grande Alá nos ha dado un cristiano cautivo que sabe hablar y escribir tu lengua tan bien como lo verás por este papel' (Miguel de Cervantes, op. cit., p. 513).

158 Cf.: "[...] y en fin se acordó por entonces que esperásemos al aviso segundo de Zoraida, que así se llamaba la que ahora quiere llamarse María [...]. Estaba allí el renegado; dímosle a leer el papel dentro de nuestro rancho, el cual dijo que así decía: Yo no sé, mi señor, cómo dar orden que nos vamos a España, ni Lela Marién me lo ha dicho, aunque yo se lo he preguntado [...]. De alli, de noche, me podréis sacar sin miedo y llevarme a la barca; y mira que has de ser mi marido; [...] la experiencia le había mostrado [al renegado] cuán mal cumplían los libres las palabras que daban en el cautiverio [...]" (Miguel de Cervantes, op. cit., pp. 514-515). 
ficción al sabio Cide Hamete Benengeli, con aventura de los galeotes y el pícaro Ginés de Pasamonte, en paralelo respecto al libro de las armas de Carranza, el desprecio de los moriscos en El coloquio de los perros y Persiles, al hilo del episodio de los falsos cautivos ${ }^{159}$, más los retratos de moros y cristianos en Los baños de Argel, La gran sultana y El gallardo español ${ }^{160}$. De hecho, basta recordar el anónimo Abencerraje (1561) y la maurofilia $v s$. maurofobia de los romances fronterizos, la versión de esta obra seguramente por Jorge de Montemayor al final del libro IV de La Diana en impresiones posteriores a la príncipe de Valencia (1558 o 1559), desde la edición de Valladolid (1561), la versión de la Historia del Abencerraje y la hermosa Jarifa por Antonio de Villegas en su Inventario (1565), La historia de los dos enamorados Ozmin y Daraja en el Guzmán de Alfarache, I, 8 (1599) de Mateo Alemán, con escenario en Sevilla, la Historia de las Guerras civiles de Granada (1595) de Ginés Pérez de Hita, con notables dosis de maurofilia, pero también, como he apuntado y así lo leyó Cervantes, la trama amorosa del canto XIV de La Austríada a propósito de la muerte de Abenhumeya.

\section{MÁS ALLÁ DEL ARS NARRANDI DE RUFO: UNA ÉPICA NOVELESCA HUMANIZADA O RETRACTACIÓN CERVANTINA DE LA TRADICIÓN CLÁSICA}

Como pudo comprobar Cervantes en su cautiva lectura de Rufo, el Jurado cordobés se había valido de distinguidos modelos clásicos para su propuesta de épica novelesca, especialmente en lo que atañe a las fronteras entre la realidad y la ficción. Se ha señalado ya a este respecto la influencia de autores de la tradición clásica como Lucano, con resonancias y ecos además en la tradición épica cordobesa a modo de continuum desde Mena

159 Véase al respecto Marie-Blanche Requejo Carrió, "«De cómo se guisa una fábula»: el episodio de los falsos cautivos en El Persiles (III, X)", en Peregrinamente peregrinos, vol. 1, pp. 861-879.

160 Puede leerse sobre este particular: Javier Rubiera, "Algunos aspectos de la construcción del espacio teatral en tres comedias de cautivos: El gallardo español, Los baños de Argel y La gran sultana", en Volver a Cervantes. Actas del IV Congreso Internacional de la Asociación de Cervantistas. Lepanto 1/8 de Octubre de 2000, coord. Antonio Pablo Bernat Vistarini, Palma de Mallorca, Universitat Illes Balears, 2001, vol. 2, pp. 1021-1034. 
a Rufo. Sin embargo, el autor de la historia del cautivo, en su voluntad de lograr un método narrativo propio y personal que le permitiese abogar por una épica novelesca humanizada, se va a servir de otras estrategias literarias que le permitirán acercarse al mundo clásico lejos de la mera mimesis, es decir, como en cierta medida había procedido Rufo, aunque con las divergencias que voy a desgranar a continuación. Me estoy refiriendo, en concreto, a una suerte de retractación o inversión de determinados mitos procedentes de modelos clásicos imitados por Cervantes tales como Virgilio y Apuleyo, con resonancias en la historia del cautivo. Comencemos con el preclaro autor de Mantua, uno de los auctores predilectos por cierto de Rufo, más allá de la modalidad de la tragedia en su canon épico-novelesco de La Eneida.

\subsection{Cervantes intérprete de Virgilio: más allá de la tragedia}

Si bien Cervantes, con vistas a su historia del cautivo, debió ser sensible a la trama amorosa en la historia épico-novelesca propuesta por Rufo en $L a$ Austríada, lo cierto es que finalmente se propuso distanciarse de dicho referente prístino en aras de la emulación. Para ello tuvo en cuenta la historia virgiliana de Dido, correlato de Zoraida, y Eneas, con su paralelo conceptual en el capitán cautivo, como vamos a ver, en La Eneida (IV, 60 ss.), por el abandono de la reina de Cartago bajo la imperiosa responsabilidad del héroe troyano para con su pueblo, hasta el punto de llevar sobre sus hombros a su padre Anquises, y su destino ${ }^{161}$. Por tanto, asistimos a una reescritura o inversión cervantina a modo de escenificación, esto es, haciendo retablo, a propósito del desmayo de Zoraida, con prefiguración previa en la Nísida de La Galatea, que transcurre ante la despedida del cautivo, héroe

161 Para la pervivencia de los modelos clásicos en Cervantes puede leerse: Juan Francisco Alcina, "Horacio en latín en Espańa (1492-1700)", Edad de Oro, 24 (2005), pp. 7-25; Juan Antonio López Férez, "Datos sobre la tradición clásica en el Quijote", Fortunatae, 16 (2005), pp. 151-162; Antonio Barnés Vázquez, "Yo he leido en Virgilio». La tradición clásica en el "Quijote», pról. Jean Canavaggio, Vigo, Academia del Hispanismo, 2009; la edición citada de La Galatea al cuidado de Juan Montero, en colaboración con Francisco J. Escobar y Flavia Gherardi, passim; así como Daniel López-Cañete Quiles, "El tiempo devorador, el tiempo descubridor: dos notas sobre tradición clásica en Cervantes", Calamus Renascens, 16 (2015), pp. 103-125; e id., "Horacio y el Quijote, II 43", en prensa. 
épico humanizado, quien, como contrapunto a Eneas, promete regresar en una retractación del nóstos homérico; no obstante, más adelante se habrá de producir un segundo desmayo, al menos en apariencia y conforme a una palinodia escenificada o performativa, de Zoraida cayendo en los brazos del cautivo, tras el reencuentro y anagnórisis de los amantes ${ }^{162}$.

Es más, esta hábil evocación de la historia amorosa de Dido y Eneas por Cervantes en un contexto épico-novelesco renovado la habría de retomar el ingenioso autor del Quijote en su épica en prosa novelada, esto es el Persiles, obra que, como en la historia del cautivo, tiene lugar la imitación de la también pareja de enamorados de El asno de oro, o sea, Psique y Cupido $^{163}$. Huelga decir sobre este particular que la omnipresencia de Venus y de Cupido como esfera simbólico-mítica del amor en el Persiles gravita de continuo sobre el amplio periplo de los protagonistas, en paralelo respecto a los avatares y visicitudes que experimentan Psique y Cupido en el relato apuleyano. Resulta frecuente encontrar, por tanto, en dicha épica novelesca el ejemplo mitológico de parejas mítico-legendarias, como las de Dido y Eneas, o Psique y Cupido, de notoria tradición humanística hispalense, que tienen como correlato literario, en la urdimbre y trama de la historia,

162 Como se recordará: "Sin duda alguna que con el sobresalto de la entrada de estos canes se ha desmayado.

Y, quitándola del mío, la arrimó a su pecho, y ella, dando un suspiro y aún no enjutos los ojos de lágrimas, volvió a decir:

-Ámexi, cristiano, ámexi. ('Vete, cristiano, vete').

A lo que su padre respondió:

-No importa, hija, que el cristiano se vaya, que ningún mal te ha hecho y los turcos ya son idos [...]; [se dirige el cautivo al padre de Zoraida:] quédate en paz, $y$, con tu licencia, volveré, si fuere menester, por yerbas a este jardín, que, según dice mi amo, [Arnaute Mamí] en ninguno los hay mejores para ensalada que en él; [...] Con esto me despedí al punto de entrambos, y ella, arrancándosele el alma al parecer, se fue con su padre [...]. Cuando ella [Zoraida] me conoció, no se detuvo un punto, porque, sin responderme palabra, bajó en un instante, abrió la puerta y mostrose a todos tan hermosa y ricamente vestida, que no lo acierto a encarecer. Luego que yo la vi, le tomé una mano y la comencé a besar; [...] yo no osé desamparar a la Zoraida, que como desmayada se había dejado caer en mis brazos." (Miguel de Cervantes, op. cit., pp. 523-526).

163 Véase Francisco J. Escobar, "Nuevos datos para la lectura de la historia de Croriano y Ruperta (Persiles, III, 17): a vueltas con los aspectos mítico-retóricos", en Humanismo y pervivencia del mundo clásico. Homenaje al profesor Antonio Prieto, pp. 287-302. 
la relación amorosa de Periandro y Auristela, así como de otros personajes actantes. No obstante, en tales fábulas de la tradición clásica prima el tratamiento de la belleza física (forma o formonsitas) y espiritual (pulchritudo) como camino de perfección para los protagonistas cervantinos, por lo que suelen destacar en ellas las historias de sesgo trágico relacionadas con el amor que aleccionan moralmente mediante la pedagogía ex contrario, en consonancia con el espíritu ejemplar de la Contrarreforma.

Pues bien, en esta línea estético-conceptual trazada en el Persiles, con paralelo intertextual en el Quijote, viene a cobrar un notorio lugar la conocida historia virgiliana de Dido y Eneas, de aliento épico-novelesco. En efecto, en el capítulo XVII del segundo libro, la hermosa Sinforosa, recuperándose de un repentino desmayo, o sea, al modo performativo de otros personajes femeninos como Nísida en La Galatea y Zoraida en la historia del cautivo, es comparada con la desdichada e infeliz reina de Cartago ${ }^{164}$. En cualquier caso, el parlamento de Sinforosa-Dido, que atiende de cerca al modelo virgiliano, llega a recrear el apunte neoplatónico de la belleza mediante la invocatio inicial y el motivo de la gallardía femenina, como le sucede en cierta medida a Psique, correlato también de Zoraida, según analizo más abajo, por sus heroicas pruebas iniciáticas que le habrán de facilitar su plena conversión y metamorfosis espiritual como elevación del alma $^{165}$. Esto es, se trata de una imitación virgiliana como otras del Persiles, así en el capítulo XIV del cuarto libro, pasaje, no obstante, en el que se viene a ponderar las cualidades de Auristela-Sigismunda, convertida en

164 Cf.: "Volvió, en fin; tendió la vista por el mar, vio volar la saetía donde iba la mitad de su alma, o la mejor parte della, y, como si fuera otra engańada y nueva Dido que de otro fugitivo Eneas se quejaba, enviando suspiros al cielo, lágrimas a la tierra y voces al aire, dijo estas o otras semejantes razones"; véase Miguel de Cervantes, Los trabajos de Persiles y Sigismunda, ed. Carlos Romero, Madrid, Cátedra, 1997, p. 391.

165 Cf.: "-¡Oh hermoso huésped, venido por mí mal a estas riberas, no engañador, por cierto, que aún no he sido yo tan dichosa que me dijeses palabras amorosas para engañarme! [...] Hija soy de un rey, y me contento con ser esclava tuya; y, si no tengo hermosura que pueda satisfacer a tus ojos, tengo deseos que puedan llenar los vacíos de los mejores que el amor tiene" (Miguel de Cervantes, op. cit., pp. 391-392). Otros ecos sobre esta pátina épico-novelesca en El Persiles ofrezco en "El binomio formonsitas / pulchritudo en el Persiles: de la belleza corpórea a la categoría simbólico-mítica”, Anuario de Estudios Cervantinos. Cervantes entre dos Siglos de Oro. De "La Galatea» al "Persiles», 3 (2007), pp. 233-256. 
la reina de Tule, es decir, uno de los lugares que marca el finis terrae, en un claro eco virgiliano (Geórg. I, 29-30) ${ }^{166}$.

Por otra parte, como complemento a la pareja mítica de Dido - Eneas, he puesto ya de relieve la pervivencia del mito apuleyano de Psique y $\mathrm{Cu}-$ pido en la historia de Ruperta (Psique) y Croriano (Cupido) en Persiles III, 17, con protohistoria previa hispalense en La Psyche de Mal Lara, con colaboración de Herrera y también de Mosquera de Figueroa, humanista cercano a Cervantes. De hecho, la conocida escena en la que la protagonista contempla detenidamente con una luz el rostro de su "enemigo" tiene, al margen de una posible reminiscencia del $A$ madis ${ }^{167}$, su modelo en El asno de oro. Por tanto, en la construcción de la pareja Zoraida - capitán cautivo, Cervantes, como hace en el Persiles, abogó por una contaminación virgiliano-apuleyana de estas parejas míticas con el objeto de distanciarse de la metodología épico-novelesca identificada en su cautiva lectura de Rufo. Pero desarrollemos seguidamente la cuestión, puesto que Cervantes enriqueció el personaje de Zoraida con otro elemento más de la tradición clásica, esto es, el arquetipo trágico de la hija traidora, también presente en la épica novelesca hispalense.

\subsection{Palingénesis humanizada de la tradición clásica: de Virgilio al arqueti- po trágico de la hija traidora}

En la propuesta de reescritura de Dido y Eneas por Cervantes, como una forma de aemulatio respecto al concepto épico-novelesco de Rufo, se identifican los estilemas épicos de sabor mitológico, cuando por amor Zoraida

166 Cf.: "Hermosa era Sigismunda antes de su desgracia, pero hermosísima estaba después de haber caído en ella, que tal vez los accidentes del dolor suelen acrecentar la belleza. Dejose caer del coche sobre los brazos de Sigismunda, ya no Auristela, sino la reina de Frislanda y, en su imaginación, también reina de Tile" (Cervantes, $o p$. cit., p. 726). Los versos de Virgilio los recuerda el propio Cervantes en el capítulo doce del cuarto libro: "[...] ac tua nautae / numina sola colant: tibi seruiat ultima Thule [...]” (p. 712). Para otros detalles circunscritos al imaginario geográfico cervantino desde la tradición literaria: Juan Antonio Garrido Ardila, "Escandinavia y el Persiles: de la Geografía a la Historia”, Anales Cervantinos, 48 (2016), pp. 221-242; y Jorge Albistur, "Persiles: desde un lugar de La Mancha a los confines del mundo", Humanidades. Revista de la Universidad de Montevideo, 2 (2017), pp. 17-43.

167 En concreto en lo que atañe al episodio de Elisena y Perión, capítulo I. 
acaba traicionando a su padre, Agi Morato. Pues bien, para la poliédrica y reticular construcción del personaje femenino, el autor de la historia del cautivo implementó en su discurso literario el arquetipo de las parejas míticas en un conflicto a tres bandas; es decir, amada, amante y padre de la heroína trágica, representado en la tradición con personajes que tienen sus resonancias a modo de protohistoria en la épica novelesca de Mal Lara, en concreto en el Hércules animoso, como Medea-Jasón-Eetes, Ariadna-Teseo-Minos, Escila-Minos-Niso, Cometo-Anfitrión-Pterelao o Hipodamía-Pélope-Enómao. Asistimos, por tanto, a una amplia recreación estética de Cervantes como una épica novelesca humanizada respecto a la tradición clásica de la que parte como arquetipo y de la que había bebido con anterioridad Rufo, allegado a los círculos humanísticos hispalenses; esto es, más cercana a la expresión verosímil de los complejos y contradictorios sentimientos, afectos y emociones del ser humano. O en otras palabras, Cervantes abogó por una retractación de la conocida historia virgiliana de Dido y Eneas apoyándose en el arquetipo épico-novelesco, con tintes trágicos, de la hija traidora, recreado por Mal Lara en el Hércules animoso, poema conocido por su amigo y compañero de Academia, Mosquera de Figueroa.

Tanto es así que en la historia del cautivo planteada en la mesa de trucos o tropelía cervantina, se viene a desarrollar esta cuestión, por ejemplo cuando la noble Zoraida se tapa los ojos con las manos porque no puede ver a su padre traicionado en esta delicada encrucijada sentimental. A su vez, no falta la importancia de la libertad y el rescate como temas netamente cervantinos, frutos de su experiencia, aplicados al padre de Zoraida y a su pueblo ${ }^{168}$, en tanto que el renegado le dice al cautivo "que lo que se podía hacer era darles libertad [a Agi Morato y al resto de moros cautivos]

168 Cf.: "Cuando su hija le vio, se cubrió los ojos por no verle, y su padre quedó espantado, ignorando cuán de su voluntad se había puesto en nuestras manos [...]. Él, como vio allí a su hija, comenzó a suspirar ternísimamente, y más cuando vio que yo estrechamente la tenía abrazada, y que ella, sin defenderse, quejarse ni esquivarse, se estaba queda; pero con todo esto callaba, porque no pusiesen en efeto las muchas amenazas que el renegado le hacía. Viéndose, pues, Zoraida ya en la barca, y que queríamos dar los remos al agua, y viendo allí a su padre y a los demás moros que atados estaban, le dijo al renegado que me dijese le hiciese merced de soltar a aquellos moros y de dar libertad a su padre, porque antes se arrojaría en la mar que ver delante de sus ojos y por causa suya llevar cautivo a su padre que tanto la había querido" (Miguel de Cervantes, op. cit., pp. 526-527). 
en llegando a la primera tierra de cristianos" 169 , en contraste respecto a la actitud de Agi Morato, quien se dirige a los cristianos ofreciéndoles dinero por su anhelada liberación ${ }^{170}$. En cualquier caso, los personajes principales, sean moros o bien cristianos, quedan retratados llorando en un sentimiento común, en calidad de conclamatio elegíaca por la desgraciada historia del padre y la hija ${ }^{171}$, en la que no están ausentes los reproches humanos de Agi Morato a Zoraida, esta haciendo gala a su vez de una actitud noble pero al mismo tiempo traidora respecto a su padre, su noble linaje y su pueblo ${ }^{172}$. Sea como fuere, en la nudosa y enmarañada trama narrativa, con fórmulas ensayadas en el laboratorio experimental de La Galatea, el renegado acabará respondiendo a Agi Morato por su hija conversa ${ }^{173}$, mientras que Zoraida le llega a confirmar a su padre que es ya

169 Cf.: "Iba Zoraida, en tanto que se navegaba, puesta la cabeza entre mis manos por no ver a su padre, y sentía yo que iba llamando a Lela Marién que nos ayudase [...]. Dimos de comer a los moros bagarinos, y el renegado les consoló diciéndoles como no iban cautivos, que en la primera ocasión les darían libertad" (Miguel de Cervantes, op. cit., pp. 528-529).

170 Cf.: "[...] desde aquí os ofrezco todo aquello que quisiéredes por mí y por esa desdichada hija mía, o, si no, por ella sola, que es la mayor y la mejor parte de mi alma" (Miguel de Cervantes, op. cit., p. 529).

171 Cf.: "En diciendo esto, comenzó a llorar tan amargamente, que a todos nos movió a compasión y forzó a Zoraida que le mirase; la cual, viéndole llorar, así se enterneció, que se levantó de mis pies y fue a abrazar a su padre, y, juntando su rostro con el suyo, comenzaron los dos tan tierno llanto, que muchos de los que allí íbamos le acompañamos a él" (Miguel de Cervantes, op. cit.,p. 529).

172 No obstante, Agi Morato le pide explicaciones a su hija ante lo anómalo de su actitud y comportamiento: “-¿QQué es esto, hija, que ayer al anochecer, antes que nos sucediese esta terrible desgracia en que nos vemos, te vi con tus ordinarios y caseros vestidos, y agora, sin que hayas tenido tiempo de vestirte y sin haberte dado alguna nueva alegre de solenizalle con adornarte y pulirte, te veo compuesta con los mejores vestidos que yo supe y pude darte cuando nos fue la ventura más favorable? Respóndeme a esto, que me tiene más suspenso y admirado que la misma desgracia en que me hallo" (Miguel de Cervantes, op. cit., p. 529).

173 Con apunte al tiempo al Libro de Job a propósito del Post tenebras spero lucem, tan cervantino por otra parte: "[...] y, así, quiero que sepas que ella es cristiana y es la que ha sido la lima de nuestras cadenas y la libertad de nuestro cautiverio; ella va aquí de su voluntad, tan contenta, a lo que yo imagino, de verse en este estado como el que sale de las tinieblas a la luz, de la muerte a la vida y de la pena a la gloria" (Miguel de Cervantes, op. cit., p. 530). 
cristiana y que no resulta responsable de la falta de libertad y desgracia en que se encuentra. De hecho, no se propuso hacerle mal alguno ni infligirle daño o castigo, sino que trató de hacerse a sí misma un bien espiritual. Por último, tras escuchar a su hija, Agi Morato trata de suicidarse arrojándose "desesperado" al mar ${ }^{174}$, en una resonancia de la tentativa anterior de Zoraida, pero finalmente lo salvan los restantes protagonistas ante las voces y gritos de dolor por parte de la atribulada joven ${ }^{175}$.

Como se ve, estamos ante un marcado contrapunto cervantino entre la realidad histórica y la leyenda, habida cuenta de que Zoraida, en correspondencia con Zara, es el arquetipo de buena mujer cristiana frente a la Cava y sus insanos amores con el rey Rodrigo ${ }^{176}$, a los que se llega a aludir en la historia del cautivo, por quienes el imperio español había sido conducido inexorablemente a la dominación islámica ${ }^{177}$. Tanto es así que Agi Morato llega a transmutar su carácter con apasionados arrebatos mediante furor $^{178} \mathrm{y}$, por su traición y "por mudar de religión", llama a Zoraida "mala hembra", "infame moza y mal aconsejada muchacha”, "ciega y desatinada", al tiempo que lamenta haberle dado la vida además de haberla colmado de regalos desde su nacimiento ${ }^{179}$. Con todo, le acabará rogando a su hija que vuelva con él a su patria y que abandone a los cristianos; de esta forma le perdonaría todo lo sucedido en tanto que podría darle ella consuelo al haber recibido tanto dolor. En cambio, lejos de esta aparente consolatio, habitual en modelos estoicos tanto para Cervantes

174 En un nuevo paralelo de Cervantes respecto a Apuleyo, dado que Psique trató también de suicidarse en El asno de oro pero no llevó a cabo su propósito gracias a la intervención de Pan.

175 Miguel de Cervantes, op. cit., p. 530.

176 Véase: Alberto Montaner Frutos, "Zara/Zoraida y la Cava Rumía: historia, leyenda e invención", en De Cervantes y el Islam. Actas del encuentro Cervantes, El "Quijote», lo moro, lo morisco y lo aljamiado celebrado en Sevilla los días 19-21 de mayo de 2005, coords. Nuria Martínez de Castilla Muñoz y Rodolfo Gil Benumeya, Madrid, Sociedad Estatal de Conmemoraciones Culturales, 2006, pp. 247-280.

177 Cf.: "[...] llegamos a una cala que se hace al lado de un pequeño promontorio cabo que de los moros es llamado el de la "Cava Rumía», que en nuestra lengua quiere decir 'la mala mujer cristiana', y es tradición entre los moros que en aquel lugar está enterrada la Cava, por quien se perdió España, porque cava en su lengua quiere decir 'mujer mala', y rumia 'cristiana'” (Miguel de Cervantes, op. cit., pp. 530-531).

178 Miguel de Cervantes, op. cit., p. 532.

179 Miguel de Cervantes, op. cit., pp. 531-532. 
como para Rufo, es el caso de Séneca y su Consolación a Helvia, Zoraida acaba manifestando que es Lela Marién la responsable de su conversión, o metamorfosis, espiritual y que será ella quien le transmita solaz y consuelo $^{180}$. En fin, el cautivo, Zoraida y los restantes personajes renaudarán el viaje trazado rumbo a España y, tras tantas peripecias características de la épica novelesca y la novela griega, arribarán a "tierra de cristianos"181. Sin embargo, en estos compases de su trama narrativa, Cervantes tiene todavía en vilo y en suspense al lector, puesto que el cautivo y los restantes cristianos, durante la azarosa travesía, sienten el "temor que de razón se debía tener que por allí anduviesen bajeles de cosarios de Tetuán, los cuales anochecen en Berbería y amanecen en las costas de España [...].” ${ }^{182}$.

\section{Modulación CERVANTINA DE LA ÉPICA MitológiCA HaCia LA NOVE- LA APULEYANA (CON SABOR POPULAR PARA OTRA PICARESCA)}

En consonancia con su retractación virgiliana y el arquetipo de la hija traidora, Cervantes trató de explorar otros caminos estéticos no tan hollados para su historia del cautivo, alejándose así de la propuesta épico-novelesca de Rufo. De hecho, cabe reparar, como he apuntado con anterioridad, en el contexto previo que precede a dicho relato a efectos de macroestructura narrativa, en concreto la imitación por parte del autor alcalaíno del episodio apuleyano de los cueros u odres de vino del africano Apuleyo; esto es, en consonancia con la tradición folclórica oral de Argel y otros enclaves afines evocados en la historia del cautivo, al margen de que se mencionen luego las patrañas de vieja, como la anus apuleyana ${ }^{183}$.

En resumidas cuentas, Cervantes debió espigar, en su prodigiosa memoria como lector, elementos y motivos novelescos de temática amorosa que entroncaban a la perfección con arquetipos folclóricos de África y de filiación apuleyana, una vez más de tonalidad hispalense, a partir del

180 Miguel de Cervantes, op. cit., pp. 530 y 532.

181 Miguel de Cervantes, op. cit., p. 536.

182 Miguel de Cervantes, op. cit., p. 535.

183 O sea, en entronque con la tradición de sabor popular de Los Refranes que dizen las viejas tras el fuego del Marqués de Santillana con una impresión al cuidado de Francisco Fernández de Córdoba en 1541. 
cuento de Psique y Cupido; es decir, con ecos a su vez en Ruperta y Croriano en el Persiles, como también en el Amor enamorado de Lope de Vega y otras obras similares de la época ${ }^{184}$. Tal proceder estético cervantino explicaría, en lo que hace a la compleja y sutil construcción de Zoraida como personaje, la amplia descripción de la belleza inigualable de la "hermosa Zoraida" por "común opinión", hasta el punto de que, cuando el cautivo y restantes cristianos llegan a "tierra cristiana", en concreto VélezMálaga, "[...] osaré decir que más hermosa criatura no había en el mundo, a lo menos que yo la hubiese visto" ${ }^{185}$; el hecho de que se encuentre encerrada y enclaustrada en la casa paterna, de la que no se menciona su nombre hasta bien avanzado el cuento a modo de paraprosdokía o efecto sorpresivo, como en El asno de oro; el que sea pretendida por nobles linajudos y autoridades de alto copete pero a la deseada espera del "príncipe maravilloso", aquí el cautivo de amor; la notoriedad de los trabajos de Psique (Zoraida) por amor y renuncia al hogar paterno, con intención frustrada de suicidio en el agua (no obstante, Zoraida manifiesta que se va a "arrojar al mar") ${ }^{186}$; el apunte a la castidad de la joven, en consonancia además con la novela griega, una de las fuentes de inspiración de Apuleyo; el reencuentro de los enamorados (anagnórisis) y el matrimonio final, esto es, como sucede en la épica novelesca en prosa de El Persiles; o, por último, la conversión o metamorfosis espiritual de la joven, todos ellos elementos que Cervantes leyó al menos en la historia apuleyana de Psique; es decir, una patrańa de sabor paremiológico o fábula contada por una vieja (anus) a Cárite ${ }^{187}$.

184 Que analizo en «El asno de oro»: un viaje de metamorfosis hacia Cervantes, Lope, Góngora y Quevedo; véase también al respecto mi artículo: "Amor, de propio amor herido: la materia mítica en El Amor enamorado, de Lope de Vega”, Anuario Lope de Vega, 12 (2006), pp. 81-112.

185 Miguel de Cervantes, op. cit., p. 538.

186 En un juego de espejos por parte de Cervantes circunscrito a la compleja relación humana entre la hija y el padre, dado que Agi Morato también trató de suicidarse, como he señalado.

187 Baste recordar algunos ejemplos, si bien desarrollo la cuestión en "El asno de oro»: un viaje de metamorfosis hacia Cervantes, Lope, Góngora y Quevedo: "Aquella misma noche volvió nuestro renegado y nos dijo que había sabido que en aquella casa vivía el mesmo moro que a nosotros nos habían dicho, que se llamaba Agi Morato, riquísimo por todo estremo, el cual tenía una sola hija, heredera de toda su hacienda, y 


\section{MATERIAM SUPERABAT OPUS: A MODO DE CONCLUSIÓN}

A la vista de los datos expuestos durante el presente análisis de comparatismo literario e intertextualidad, resulta visible el consciente y meditado maridaje de canon culto y cultura popular tanto en Rufo como en Cervantes; es decir, desde la pátina heroica épico-novelesca, con modulación hacia la tonalidad africana en virtud de los baños de Argel, con calas en Orán, Sargel, Tetuán y otros enclaves, hasta las historias de Dido como reina de Cartago en La Eneida y Psique del erudito mago de Madaura, sin olvidar tampoco la inserción de refranes, cuentos y consejas de viejas en la línea de El asno de oro, de tradición humanística hispalense, el Decamerón y el Patrañuelo de Timoneda. El ingenioso autor de la historia del cautivo trató sobre todo de explorar caminos no tan hollados y transitados hacia otra épica más humanizada, atendiendo a la experiencia de la soldadesca compartida con Rufo, y que había leído a efectos de ficción en su obra, diferente a la a noticia del "artificioso" Torres Naharro, como señala el autor alcalaíno. Para ello, el autor del Quijote, al trasluz del concepto épico-novelesco de Rufo, prestó atención a la intrahistoria de los soldados, la vida cotidiana y los detalles, a veces marginales, como escenificación humanizada y ejemplar entre la realidad y la ficción o la vida como obra de arte; o sea, como autorrepresentación autorial y el discurso de la vida tanto para otro concepto de épica como también para otra picaresca de filiación apuleyana en una réplica, de paso, al concepto narrativo monológico de Mateo Alemán en su Guzmán, en el que se incluía la historia de Ozmín y Daraja.

Además, Cervantes debió estar atento a la tonalidad y tratamiento épico-novelesco planteado por Rufo en Apotegmas, en relación intertextual a su vez con La Austriada, como he analizado en estas páginas. Ello explica

que era común opinión en toda la ciudad ser la más hermosa mujer de la Berbería; y que muchos de los virreyes que allí venían la habían pedido por mujer, y que ella nunca se había querido casar, y que también supo que tuvo una cristiana cautiva, que ya se había muerto; todo lo cual concertaba con lo que venía en el papel" (Cervantes, op. cit., pp. 513-514); para otros pormenores sobre Zoraida, con El asno de oro al fondo: Eric C. Graf, "Cervantes es a Apuleyo lo que Zoraida es a Isis: Don Quijote como apropiación cristiana de la trayectoria protofeminista de la novela pagana", en Estas primicias del ingenio. Jóvenes cervantistas en Chicago, Madrid, Editorial Castalia, 2003, pp. 99-112. 
la prefiguración in nuce de temas plenamente cervantinos compartidos por Rufo con el objeto de "mostrar retablo". A saber: poeta con espada, cautiverio y libertad, amistad, inserción de la trama amorosa, moros y cristianos..., hasta llegar al discurso de la vida del cautivo precedido del de las armas y las letras por don Quijote con el episodio apuleyano de los cueros de vino al fondo; o en otros términos, en calidad de etología y conducta humana con vistas a la ejemplaridad en un discurso "verdadero" de la vida. Tanto es así que, si se atiende a la historia del cautivo, Rufo había auspiciado, acaso como profecía ex eventu, a la manera de su monumental epopeya, el ideal estético cervantino de "mostrar con propiedad un desatino", porque, en palabras del Jurado de Córdoba, se trataba de proponer una "novela que, pareciendo gran mentira, fuese verdad o tuviese apariencia dello". ¿Materiam superabat opus? ¿La formalización estética y modo cervantino superó la materia propuesta por Rufo al calor, reescritura y palimpsesto de autores como Virgilio y Apuleyo? A buen seguro este último pasaje de Cervantes, cautivo lector del autor cordobés, pueda responder a tales interrogantes, puesto que viene a recordar el juicio valorativo de la historia del cautivo por don Fernando en Quijote I, 42 ("Que trata de lo que más sucedió en la venta y de otras muchas cosas dignas de saberse"):

-Calló en diciendo esto el cautivo, a quien don Fernando dijo:

—Por cierto, señor capitán, el modo con que habéis contado este estraño suceso ha sido tal, que iguala a la novedad y estrañeza del mesmo caso: todo es peregrino y raro y lleno de accidentes que maravillan y suspenden a quien los oye; y es de tal manera el gusto que hemos recebido en escuchalle, que aunque nos hallara el día de la mañana entretenidos en el mesmo cuento, holgáramos que de nuevo se comenzara ${ }^{188}$.

188 Miguel de Cervantes, op. cit., p. 540. 